\title{
Education and Migration Choices in Hierarchical Societies: The Case of Matam, Senegal is
}

\author{
Emmanuelle Auriol ${ }^{a, *}$, Jean-Luc Demonsant ${ }^{\mathrm{b}}$ \\ ${ }^{a}$ Toulouse School of Economics (ARQADE and IDEI), Université des Sciences Sociales de Toulouse, \\ 21 Allées de Brienne, 31000 Toulouse, France \\ ${ }^{b}$ Facultad de Economía, Universidad Autónoma de Nuevo León, \\ Av. L. Cárdenas 4600 Ote. Fracc. Residencial Las Torres, Monterrey, NL C.P. 64930, Mexico.
}

\begin{abstract}
This paper examines determinants of schooling in traditional hierarchical societies with an established history of outmigration. In the village, a ruling caste controls local political and religious institutions. For children who do not belong to the ruling caste, migration is a strategy to increase social mobility, a process that is enhanced by formal schooling. Since formally educated migrants tend not to return to the home community, the ruling caste seeks to develop family loyalty by choosing religious education instead. The theory hence predicts that the social status of the family has a significant impact on the parental educational choices of future migrant children. Children from the ruling caste who are encouraged by their parents to migrate have a lower probability of being sent to formal school than children from the low caste. The theoretical predictions are tested on data from the Matam region in Senegal, a region where roughly one of every two children have ever attended school.
\end{abstract}

Keywords: Schooling; Migration; Social Status; Haalpulaar

JEL classification: I21, O12, O15, O17, Z13.

\footnotetext{
We would like to thank the French Development Agency (AFD) for its financial support and seminar participants at Paris School of Economics, at Banco de Mexico and at the Migration and Development Conference in Harvard for useful comments on an early version of the paper, especially Sylvie Lambert, Gary Fields, Alejandrina Salcedo, Calgar Ozden, Jean-Marie Baland and Pierre André for their insightful advice and suggestions without implicating. During the research in Senegal, financial supports from both the French ministry in charge of Higher Education (Aires Culturelles grant, 2001) and the French ministry of Foreign Affairs (Lavoisier grant, 2003-04) must be gratefully acknowledged along with Jean-Paul Azam. Ousmane Ba, Moussa Ly, Abou Sow, Abou Thiam and Hamath Thiam provided excellent field support. We owe Jacqueline Hagan a lot for her generous proofreading. Finally, we are extremely grateful for the thoughtful comments and suggestions provided by two anonymous referees and the guest editor, Hillel Rapoport, on the paper. It has greatly improved thanks to their help. All remaining errors are ours.

*Corresponding author.

Email addresses: emmanuelle.aurioletse-fr.eu (Emmanuelle Auriol ), jeanluc.demonsant@uanl.edu.mx (Jean-Luc Demonsant)
} 


\section{Introduction}

While migration policies are being designed to trigger development in sending countries, there is a need to better understand the effects of these policies on educational outcomes. Most of the literature on the impact of migration on education focuses on the impact of parental migration on children's education. The question as to whether parental migration increases investment in schooling is still very much debated. Our paper takes a different view on the topic. We investigate how the expectation of future remittances from children living abroad influences parental decisions about the education their children receive before migration. The paper is thus related to the "investment hypothesis" literature where the remittances of migrant children are repayments to their parents of implicit loans used to finance their education. ${ }^{1}$ This raises the issue of the children incentives to repay the "loans" once abroad. The investment hypothesis literature glosses over this incentive problem by assuming a perfect coordination among the family members. In sharp contrast with this approach, we show that the lack of enforcement mechanism to make children remit leads to strategic under-investment in schooling by some type of parents.

Our study takes place in a highly stratified rural community, in which religious, political and economic resources are controlled by a ruling elite caste, which represents about $40 \%$ of the village (male) elders. Based on data collected by one of the authors between April and September 2004 in Matam, rural Senegal, the paper shows a negative impact of migration on the formal education of children from the ruling caste. Hence, we observe, for this caste, the opposite result of what is expected from the investment hypothesis literature: the children who are not sent to (formal) school remit more to their parents than those who have been sent to formal school. This result is explained by the fact that the parents have only imperfect instruments to control their migrant children while they are away. The ruling caste chooses to provide a religious education rather than a formal one to their future migrant children so that they can join the village ruling elite upon return if they decide to do so. ${ }^{2}$ Indeed, if they stayed abroad in the modern economy, not

\footnotetext{
${ }^{1}$ For more on this see Rapoport and Docquier (2006) which reviews the literature on motivations to remit and in particular the investment hypothesis.

${ }^{2}$ Still, the cost of formal education is higher than the religious one (see section 2.2), which corroborates
} 
only the absence of formal education would limit their economic opportunities, but they would also suffer social stigma. Since their social status is higher at home than abroad, uneducated migrants from the ruling caste have strong incentives to return and hence to send substantial remittances while abroad. This effect, which does not hold for families of lower castes, highlights the negative effect of migration on educational outcomes.

The Millennium Development Goals aim at universal primary education for 2015, but in 2004, the primary education enrollment ratio was $76 \%$ for Senegal. ${ }^{3}$ This figure hides great regional disparities mostly along the rural-urban divide. In the study region, primary school enrollment rate was still a low $60 \%$ in 2006 according to the Senegalese National Statistical Office (source: Situation Economique et Sociale de la Région de Matam, 2007). This low enrollment is believed to be arising from the supply side, i.e., the quantity and quality of schools. Yet, the UNESCO (2007) claims that "the issue of universal access to primary education is currently being resolved in Senegal". Nonetheless, when schools are located at reasonable distance, as it is the case in the villages of our study, it is hard to argue that access is what prevents children from getting a formal education. But there are additional factors. Other explanations include the low perceived returns to education and the opportunity cost of child labor. Returns to education in traditional agricultural activities are low compared to returns in the urban modern sector. ${ }^{4}$ As a consequence, if low returns in agriculture explain why investment in education is low, the prospect of migration should alleviate the problem. In urban centers, education has higher returns so that parents of prospective migrants should have the incentives to invest in their children's education. This is what the new literature on the so-called "beneficial brain drain" or "brain gain" suggests. The central assumption of Mountford (1997) and Stark et al. (1997, 1998), who initiated this literature, is that the possibility of migration raises expected returns to education, which works as an ex-ante positive incentive to invest

\footnotetext{
that the investment hypothesis theory does not hold here.

${ }^{3}$ In 2008, the (gross) primary enrollment is $84 \%$ (source: Senegal at a Glance, World Bank, 2009). However, these ratios are based on the number of students formally registered in primary school and therefore do not necessarily reflect actual school attendance.

${ }^{4}$ According to the ILO definition of child labor, a third of Senegalese children work. Montgomery and Hewett (2005) find an urban advantage for children's primary schooling in Senegal and relate it to the absence of secondary schools in rural areas and therefore the limited motivation of parents to send their children to school (see also Amelewonou et al., 2003).
} 
in human capital of future migrants. ${ }^{5}$

The empirical evidence has not always found consistent support of a significant effect of migration on investment in education. At the macro level, Beine et al. (2008) shows that in some countries having both low levels of human capital and low emigration rates of skilled workers favors brain gain. They instrument the endogenous "skilled migration rate" variable by the country's population size and migration stock. According to their study, Mali is shown to have a brain gain, which suggests that neighboring Senegal should probably experience a brain gain too as both countries share very similar socio-economic characteristics. Recent empirical microeconometric studies yield mixed findings. In their respective studies in El Salvador, Phillipines and Mexico, Cox-Edwards and Ureta (2003), Yang (2008) and Alcaraz et al. (2012) find that remittances favor schooling, using various econometric strategies to account for the endogeneity of remittances and schooling. In the Cape Verde study, Batista et al. (2012) find that increasing the probability of own future migration increases the probability of completing secondary schooling. However, Kandel and Kao (2001) find more balanced results in Mexico: children in migrant households have higher grades, but they have lower aspirations, i.e., they have less motivation to pursue beyond average years of schooling. Finally, both Antman (2011) and McKenzie and Rapoport (2011) find negative effects of parental migration on children schooling in Mexico. According to Antman (2011), the migration of the father reduces study hours in the short run. Similarly, McKenzie and Rapoport (2011) find that family migration depresses school attendance and attainment. The negative results are explained by the illegal nature of the migration, which yields lower returns to education, and as a consequence lowers investment in human capital in migrant households. Hence, these results illustrate that migration prospects can also act as a deterrent to investments in education.

The literature on brain gain and on the investment hypothesis implicitly assume that family members are able to efficiently bargain among themselves, or that parents, who are responsible for educational choices, are benevolent (unitary model of the household). According to this logic, school attendance should increase if education leads to higher

\footnotetext{
${ }^{5}$ See two good recent review papers on the topic: Gibson and McKenzie (2011) and Docquier and Rapoport (forthcoming).
} 
returns to migration. However, our analysis reveals that moral hazard problems and incentive issues within the household can lead to strategic under-investment by some parents. To instill obedience and family values, and thus a high level of remittances, the ruling caste chooses to educate less their future migrant children than their non migrant siblings by sending them to a religious rather than a formal school. By contrast, parents from lower castes choose formal education for their future migrant children. Since the latter have less incentives to return if they migrate, it is pointless to prevent them from getting a formal education.

Previously, the social status of the family within the village has been identified as an important determinant of migration and remittance behaviors. ${ }^{6}$ In a study conducted in Kayes, Mali (a neighboring region of Matam, Senegal, where our data come from), Azam and Gubert (2005) found that migration is a strategy to "insure the family pride" because remittances prevent high-caste families not to fall below some income threshold that would keep them from maintaining their high rank in the village. In the case of India, Luke and Munshi (2011) also find that the caste system is a significant determinant of mobility: women from historically disadvantaged castes are more likely than women from any other caste to have their children residing outside the ancestral community. Our concern is also with how social status and caste rank influence parental educational choices for their prospective migrant children. By studying educational choice in the context of a socially stratified society, our paper is close to Munshi and Rosenzweig (2006), who examine the impact of caste on schooling choices. They find that lower-caste girls are more likely to favor English school over local language school, thus "taking advantage of the opportunities that became available in the new economy". In this paper, we find very similar behavior for the lower caste sons, who are more likely to be sent to a formal school than sons from the ruling elite.

To guide the analysis, we model the educational choice made by self-interested parents with different social statuses. Our specification of preferences has the property that status

\footnotetext{
${ }^{6}$ As defined by Weber (1922), social status is "an effective claim to social esteem in terms of negative or positive privileges". He argues that a status ranking is not directly related to wealth or income though it may be affected by them. This is especially true in traditional societies where social stratification is based on position in a caste system (e.g. the Indian or African caste systems).
} 
and income are complements: as sociologists would put it, agents exhibit a taste for status congruence (see Auriol and Renault, 2002, 2008). This property implies that the marginal utility of income increases with social status. Parents have the choice between sending their children to formal schools or not. The returns to education depend on whether or not children will migrate (i.e, internationally or internally). ${ }^{7}$ The returns to formal schooling, where children learn how to read and count, are higher if the child migrates. We derive various predictions from our model that we test on data from the Matam region. The case study has particular policy relevance since it combines a high emigration rate with a feudal caste system and a low primary school enrollment.

If ruling class parents consider sending their children abroad, they choose not to send them to a formal school (they rather choose Koranic school), while parents from the lower castes choose formal schooling. This result comes from the fact that self-interested children send substantial remittances to their parents only when they plan to return home. If the children decide not to return, then they have no incentive to send money to their relatives. They only send a minimum out of altruism and/or guilt. Parents from the ruling caste purposefully do not choose formal education for their future migrant children so as to maximize the differential in status levels (i.e., marginal utility of income) between home and destination. This strategy is a key instrument to ensure the loyalty of their children that they combine with the "strategic bequest motive". ${ }^{8}$ In host areas, the adult children generally occupy low-wage low-status jobs. The substantial remittances they manage to send home are partly invested in physical capital by their parents. When the migrants return home, they enjoy their elevated social status together with the resources derived from the accumulated family physical capital. By contrast, children from low castes have less incentive to return home. Migration becomes their only way out of the rigid hierarchical caste system that prevails in the village. When children from the low caste leave, it is thus often permanently. Their parents have less incentive to prevent them

\footnotetext{
${ }^{7}$ In our sample, over a third of migrants remained in Senegal, mainly in the capital city of Dakar.

${ }^{8}$ This classical motive was first invoked by Bernheim et al. (1985). As children compete for parents' inheritance, parents can threaten their children not to bequest them anything if they had not being supportive. Accordingly, young children remit to secure their bequest. In Botswana, Lucas and Stark (1985) found that wealthier families in terms of cattle ownership receive more remittances. Hoddinott (1992) tested this model on rural Kenyan data, and found remittances responsive to bequestable lands.
} 
from getting a formal education. If their children are altruistic, the parents might receive remittances, the amount of which varies according to the earned income of their children abroad. Their income being higher if they have been to formal school, parents prefer to send them there. Thus, two types of migrants exist based on social status. Migrants from the most prestigious families migrate temporarily as a means to augment their social status in the village and return to enjoy their advantageous position. Conversely, migrant youth from low caste families have little incentive to return because of the social stigma attached to their caste at home. A key determinant of their social mobility in domestic and international urban labor markets is the human capital acquired from formal schooling before migration. The theory predicts lower levels of formal education among ruling caste migrants, but a higher level of remittances. The data confirms this prediction.

The paper is organized as follows. The first section presents the institutional setting. The Matam region and the Haalpulaar society are first briefly described in section 2.1, educational choices in the Matam region are accounted for in section 2.2, while section 2.3 describes the past and present migrations of the Haalpulaaren. Section 3 presents the model and the theoretical analysis. Remittance and return strategies are analyzed in section 3.1, and migration and education decisions in section 3.2. The relevance of the theory is assessed with the help of an original dataset, which is described section 4 . The empirical analysis is conducted section 5. Results on remitting, migration, and education decisions are presented respectively in section 5.1, 5.2 and 5.3. Section 5.4 offers one robustness check of previous results investigating who is more likely to migrate within the family. Finally section 6 offers some concluding comments.

\section{The institutional setting}

\subsection{The region of Matam and the Haalpulaar society}

Matam is located in the Senegal River middle valley in a semi-arid environment surrounded by deserts: the Sahara to the North and the "Ferlo" (semi-arid plains) to the South. The population is ethnically homogeneous: the Haalpulaaren represent the vast majority. ${ }^{9}$ Matam is $400 \mathrm{~km}$ upstream from Saint-Louis connected by a national road fol-

\footnotetext{
${ }^{9}$ Also known as "Tukulors" or "Toucouleurs" in French. "Haalpulaar" (plural Haalpulaaren) means those who speak "Pulaar" (aka "Fulfulde") their vernacular.
} 
lowing the river which is badly kept and hence continuously in poor conditions. Because of its remoteness, there are no industries so that the majority of the population works on family farms. Local economic activities include agriculture, cattle breeding and fishing. Three main agriculture types coexist: rain-fed, flood-fed and irrigated crops. The villages are unequally endowed with different land qualities: irrigated lands are exclusively found next to the river banks, whereas flood-fed agriculture is practiced in backwaters as well. The natural annual river flood have allowed farmers with plots in the lowlands to reap an additional harvest during the dry season. The control over those fertile lands gave the economic power to the local aristocracy.

Similar to other Sahelian societies, the Haalpulaar society is highly stratified. Statutory groups inherited from former African empires still strongly determine the social status of a family in the village society. ${ }^{10}$ These groups are initially based on the division of labor and responsibility between "nobles", artisans and slaves.

The nobles, also referred to as "free men", represent a rather heterogeneous group: mixing both political leaders and commoners. At the top of the hierarchy are the "Torrobe" who are the religious leaders, along with some "Fulbe", traditionally cattle breeders. Usually of lesser prestige than former sub-categories are the fishermen, "Subalbe" and the warriors, "Sebe". It is usually the case that not all sub-categories can be found in each village, and usually one category dominates. ${ }^{11}$ The most prestigious category, the "Torrobe", emerged in the 18th century as a new elite formed by Muslim clerics. This group was open for a short period of time to anyone mastering the Koran, but it quickly closed (N'Gaide, 2003). Still today, they have a monopoly on religious powers: most imams and Koranic masters originate from the "Torrobe" caste. The nobles are the traditional land holders.

The artisans, "Nyenbe" are referred to as the "les castés" in French as this group matches best the idea of caste with job specialization (along with the usual endogamous feature it shares with the other categories). All the traditional crafts are represented from

\footnotetext{
${ }^{10}$ According to Tamari (1991), this organization originates from the Mali Empire in the 13th century. The region known as "Tekrur" in the 10th century, was first annexed by the Ghana Empire and then by the Mali Empire from the 13th until the 16th century.

${ }^{11}$ In reality there exists many other subgroups. For a complete description of the Haalpulaar organization see Wane (1969).
} 
the blacksmith "Waylibe" to the leather workers "Sakebe" and the wood workers "Laobe". Along with the craftsmen are the bards, "Griots" in French, "Aolube" in Pulaar. Today, artisan families do not necessarily practice in their traditional specialized activity but they usually still have been transmitting the know-how of their job. They cannot have access to the local political power.

At the bottom end of the pyramid, are the former slaves "Maccube", rather called "captives". In fact, at times of wars and "jihads", prisoners ended up as slaves. As a result, many family names of slaves are of other ethnic group origins, and as a consequence stigmatized, although many slaves took the name of their master. During almost seven centuries, it was common to change status due to wars: slaves would be turned into free men (nobles) to become warriors and noble prisoners would be enslaved. Ironically, the official abolition of the former caste system in 1848 put an end to this specific mobility, thus becoming rigid social barriers. ${ }^{12}$ As a result, although it was legally banned more than a century ago, slave status has evolved slowly.

Today in Haalpulaar society, social recognition is based on one's lineage and the prestige of one's lineage is assessed with regard to one's statutory group. N'Gaide (2003) explains that when two Haalpulaaren meet they ask each other their family names and try to trace back the patrilineal branch of the family tree to identify who they are talking to, in order to pay deserved tribute according to the ancestors' prestige. Descendants of slaves are expected to be deferential to nobles, to cook on festive occasions and sometimes repair their houses. ${ }^{13}$ They distinguish themselves by their willingness to work hard (see Klein, 2005). An illustration of their position in the society can be found in "joking relationships". Depending on one's family name, one is allowed to tease people from another clan (one's "joking kin") without offending anybody. Usually, the jokes are very humiliating and are centered on either greed for food or calling the other "my slave". Similarly, some body and verbal languages are directly linked with low caste. For instance, nobles would rather not use insults in order to avoid being mistakenly taken for an artisan or slave (e.g., again, see Klein, 2005). N'Gaide (2003) emphasizes that each person must act

\footnotetext{
${ }^{12}$ In Senegal it is in 1901 that the law starts to be enforced, and become efficient in 1906 . See for instance Delaunay (1984, pg. 43), Klein (2005) and references within.

${ }^{13}$ Each year after the rainy season, traditional mud houses need to be repaired, especially the roof.
} 
according to his statutory group at the risk of being rejected: anyone who would decide to reject the social hierarchy would be treated as a fool and consequently excluded from the society.

Discrimination and stigmatization suffered by artisans and slaves, are restrictions on land access, and political and marital constraints. In the private sphere of marriages, there are many restrictions. Above all, men from the artisan and former slave categories are not allowed to marry noble women. For this reason, parents of the bride are very active in the selection of the prospective groom, and are particularly cautious when dealing with men of distant village, inquiring about his actual social origin.

Probably the greatest stigmatization in a gerontocratic village society is being a patriarch but not having a say outside the family circle. Local dignitaries descending from lineages of village founders and other prestigious families, referred to in the sequel of the paper as the "ruling caste", make up only a fraction within the "free men" category, the rest, referred to in the sequel of the paper as "low caste", being, along with the majority of the artisans and slaves excluded from the village political life. ${ }^{14}$ The low castes do not vote for the village chief and are not entitled to accede to local political power, nor become religious leaders, which, as we saw, is an exclusive privilege of the "Torrobe". The ruling caste are the village dignitaries: the village chief and other eligible families and members of the village council who nominate the village chief, usually picked among few main families. ${ }^{15}$

\subsection{Schooling choices in the Matam region}

In the six villages surveyed, each village possesses a formal primary school at the time of the survey. The most recent primary school opened 6 years before the survey. So that school attendance should not be subject to access constraints for the youngest cohorts, but probably comes into play for older ones. Figure 1 displays the percentage of all men

\footnotetext{
${ }^{14}$ Actually, a small fraction of artisans and slaves can have access to local political power. They usually represent the former slaves or artisans attached to the most prestigious families. Symmetrically, as mentioned earlier, some noble families are not part of the ruling caste. However, concretely, which families belong to the ruling caste is largely based on their caste origin, as the data shows: the ruling caste represents $40 \%$ of all sampled families, but for instance, around $60 \%$ of the "Torrobe" belong to the ruling caste, while only around $30 \%$ of all the artisans and some slaves do so.

${ }^{15}$ Schmitz (1994) shows that there are indeed dynasties of village chiefs spreading over centuries.
} 
and women living in the villages (7 years and older) who have ever attended formal school, by age groups. As expected for both men and women, the graph is decreasing showing that formal schooling is a recent phenomena.

Figure 1: Percentage of all household members living in the village who have ever attended formal school by age group and gender.

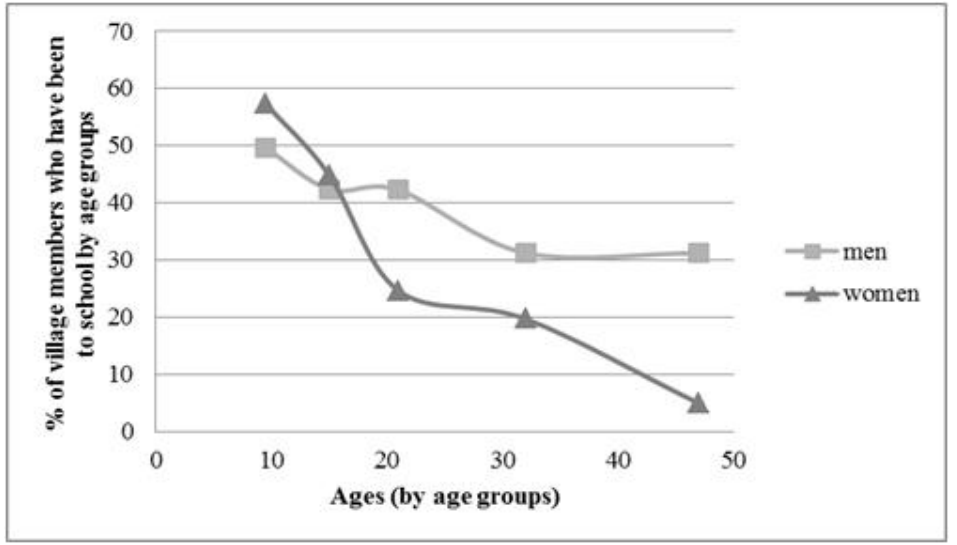

More interestingly, although access to formal primary school is not an issue for the youngest cohorts, only $51 \%$ of the 7 to 17 year-old children are enrolled, which was the national level 10 years ago. It is also striking that $35 \%$ of households do not send any children to formal school at all. Despite the presence of a school nearby, in our sample, the primary enrollment rate is very low for school age children living in the villages. Apart from the low perceived returns to education in rural areas, André and Demonsant (2009) based on a 2003 Senegalese household survey, suggest that Koranic studies represent an actual barrier to formal school attendance. ${ }^{16}$

Historically, the Haalpulaaren are responsible for spreading Islam all over West-Africa, and are highly respected for that in the sub-region. Senegal is predominantly Muslim, but similar to other countries under former French colonial rule, state schools offered little or no religious education. So children are sent to informal Koranic schools. Because of their informal nature, Koranic schools do not have any precise structure (timetables,

\footnotetext{
${ }^{16}$ If both school systems are to some extend compatible, Koranic school being in the form of after-school programs, André and Demonsant (2009) show that they tend to be substitutes rather than complement. This is especially true when boys (rarely girls) are sent to boarding schools in which the student lives with and studies under the direction of a Koranic master. In the latter form, as full time is required to the student, it is more difficult to reconcile with formal schooling. A detailed description of Koranic schools in Senegal is given in André and Demonsant (2009).
} 
curricula...). Students are taught Koranic verses for their daily prayers in the Arabic language, which they rarely master in the end. This raises the question as to what skills are actually transmitted in Koranic schools. By contrast, in formal primary schools, children learn how to read, write, and count in French, the official language of Senegal.

André and Demonsant (2009) suggest that the main economic attractiveness of Koranic schools resides in the building of reliable networks. Bonding under the authority of a common Koranic master develops a strong sense of group identity. Huet-Gueye and de Léonardis (2005) using a lexical and morphosyntactical analysis of parents' perceptions vis-à-vis the Senegalese modern society, show that traditionalist versus modernist views seem to shape Koranic versus formal schooling choices. In Akerlof (1976) words, the Koranic school can hence be seen as a "loyalty filter". Following arguments in Becker (1993) and Becker (1996), parents try to instill a feeling of guilt if children are not loyal to them. Hence, investing in religious and traditional educations, which inculcate family values, could be instrumental to shape a son's loyalty before sending him abroad. ${ }^{17}$

\subsection{Past and present migrations}

The Haalpulaaren have a long tradition of internal and international migrations (e.g., see Diop, 1965; Delaunay, 1984; Minvielle, 1985). It has long been a household strategy to cope with agricultural risks resulting from the harsh climate of the region. While Dakar, the capital of Senegal, is the most common destination for the Haalpulaaren (see Diop, 1965), they also have an established history of international migration to other African countries (Côte d'Ivoire, Cameroon, Gabon, Sierra Leone, Congo,...) ${ }^{18}$ and France, and more recently to Italy, Spain and the US. Well established networks link Haalpulaar families to these multiple destinations where they find jobs in the service sector, the most common of which is cook, an occupational niche established during colonial rule.

Nowadays, the economic success of a family depends on the receipt of workers' remittances. Azam and Gubert (2005) further upstream the Senegal River, and Demonsant

\footnotetext{
${ }^{17}$ The value of the investment is however much lower than the formal school one as no tuition, material nor uniform is required (in some public primary school material and a uniform may be required). More on this in André and Demonsant (2009).

${ }^{18}$ Bredeloup (1994) gives a detailed account of Haalpulaar diamond diggers and merchants first in Sierra Leone and Côte d'Ivoire, then in Congo and more recently as far as Zambia.
} 
(2007) in Matam both show that the migration of family members is a way to maintain the social order for high caste families. Indeed, a great portion of remittances are redistributed in the village to secure the dominant position of the ruling caste through gifts to their clientele during religious ceremonies. Hence, central to the understanding of the parents' strategies concerning schooling is the problem of providing incentives for their children to remit.

Migration is also an exit strategy for the low-caste people. As the village society is characterized by strong social rigidities, migration is a way out of the discrimination trap. In West Africa, there are several historical accounts of the migration of slaves, who chose to migrate to urban centers or abroad to escape the social condition in their village. Klein (2005) mentions the massive exodus of slaves when transactions in persons were banned in 1905 and when the "tirailleurs", who were $75 \%$ slaves, decided not to return to their home communities after the end of the First and Second World Wars. ${ }^{19}$ Similarly in India, this is illustrated by Luke and Munshi (2011) where low-caste are more likely to leave their ancestral community. A key to their social mobility in urban centers or abroad, would then be their educational level. In what follows we study how the educational choice is made by parents of different castes.

\section{The model}

We consider education and migration decisions in a hierarchical society. We denote by $e$ the educational choice of the parents: $e=1$ corresponds to formal schooling while $e=0$ corresponds to no formal education. ${ }^{20}$

In the village economy, status allocation is embedded into an exogenous and rigid system of castes ascribed at birth. Individuals are born into the high caste (i.e., the ruling caste), denoted $h$, or the low caste (i.e., the non ruling caste, mostly commoners, slaves and artisans), denoted $l$ so that their status ordering is $s^{h}>s^{l}$. By contrast, in modern economies, social status is related to economic success and material well-being

\footnotetext{
${ }^{19}$ Tirailleurs are Africans who served in the French colonial army. The first tirailleurs were from Senegal, so the units were often referred to as the "Tirailleurs Sénégalais".

${ }^{20}$ If the child does not receive a formal education he can still be send to religious school (e.g., Koranic school) or he can receive no education at all (nor formal, nor religious). Since the paper focus on formal schooling, we do not distinguish among the last two options.
} 
and stems mostly from relative income or wealth (see Veblen, 1899). When the child migrates, denoted $m$, his status abroad depends on the level of formal education level (either directly as illiterate people are suffering from social stigma, or indirectly through income effect) but it does not depend anymore on his birth: $s^{m i}(e)=s^{m}(e) \forall i \in\{l, h\}$ so that $s^{m}(1)>s^{m}(0)$. One important assumption for our results is the relative ordering of social status at destination and at home. Social mobility is more fluid in a modern economy than in a traditional caste system. This translates into $s^{l}<s^{m}(1)$ : the status of a low caste is lower than the status of an educated worker in a modern economy. Similarly, a member of the ruling elite has higher prestige in his community than an illiterate migrant worker in a modern economy: $s^{m}(0)<s^{h}$. The following assumption summarizes the social status ordering between the village and the migration destination.

A1 $s^{l}<s^{m}(1)$ and $s^{m}(0)<s^{h}$

Since in general there is no obvious ranking between the social status of an uneducated worker in a modern economy, $s^{m}(0)$, and the status of a low caste in the hierarchical society, $s^{l}$, nor between the social status of an educated worker in a modern economy, $s^{m}(1)$, and the status of a high caste in the hierarchical society, $s^{h}$, we do not make any specific assumptions about these relative orderings.

Abroad, wages depend on the formal education level, $w^{m}(e)$, while at home they are independent of education, $\underline{w}$, capturing the low return of formal education in traditional agricultural economy. Consistently with empirical evidence we assume that

A2

$$
\underline{w}<w^{m}(0)<w^{m}(1) .
$$

Following Auriol and Renault (2008), we define the instantaneous utility of agent $i$ as:

$$
u^{i}\left(w^{i}, s^{i}\right)=w^{i} s^{i}
$$

where $w^{i}$ is the income and $s^{i}$ the social status of the agent $i \in\{h, l\}$ at the time of consumption. This specification of preference reflects in a simple manner the agents' taste for consumption and status. Since income and status are both positively valued, indifference curves relating these two variables are strictly decreasing, reflecting substitution between the two. However, they are not a perfect substitute: a prestigious status does not com- 
pensate for the absence of income; nor does a good income make up for an humiliating status. Indeed, convexity of preferences implies some complementarity between social status and income.

Individuals live for three periods: childhood, adulthood and old age. We set, without any loss of generality, the agents' discount factor, which is supposed to be equal to the growth rate of the economy, which is also the interest rate of the agents' savings abroad, to $1 .{ }^{21}$ Children and old people are unproductive. Education occurs in the first period, work (either at home or abroad) in the second period, and retirement in the third period. Since social security and formal retirement plans are sparse in the Matam region, parents rely mainly on the financial support of their children, especially their migrant ones, during old age. We denote by $r$ the share of income a migrant children send to his family. It is a social obligation to support aging relatives, so that there is a minimum share of his income, denoted $\underline{r}>0$, that a migrant child will send (out of altruism or guilt) to support his old parents. ${ }^{22}$

We focus on future migrant children. There are sequential choices for each type of agent $i \in\{l, h\}$. In chronological order, the parents move first and the child moves next: The parent $i$ chooses 1$)$ to send the child to a formal school or not, $\left.e^{i} \in\{1,0\}, 2\right)$ to invest a share of income in durable $\alpha^{i} \in[0,1]$. The migrant child $i$ decides 1$)$ to remit, $\left.r^{i} \in[\underline{r}, 1], 2\right)$ to return, $R^{i} \in\{0,1\}$. All the variables are dummy variables, but $\alpha^{i}$ which belongs to $[0,1]$ and $r$ to $[\underline{r}, 1]$.

Finally, we assume that individuals, who are self-interested, are expected utility maximizers. Parents will send a child to a formal school if and only if the expected benefit for them is higher than if the child is illiterate. Similarly, a child will remit and return home if and only if his expected utility is higher than when he does not remit. We first examine the migrant's incentive to remit.

\footnotetext{
${ }^{21}$ Choosing $\delta \neq 1$ will not change the results of the paper (computation available upon request). The important assumption is that $\delta$ is equal to the interest rate of the agents' savings abroad. This assumption means that individuals can smooth consumption across periods if they do not return. It avoids introducing a bias against or in favor of saving.

${ }^{22}$ If on average the minimum level of remittances is low, as it is the case in our database, some parents will have interest in perpetuating the caste system and will want their children to return home. If the average minimum remittance is large then it is always optimal to permanently send formally educated children abroad and to live on the minimum they send.
} 


\subsection{Remittances and Return}

If the migrant plans to return, he will remit. Otherwise, he will not be welcomed home upon return. The remitting and return decisions are hence joined. If the migrant remits, the parents invest a share $\alpha \in[0,1]$ of the remittances in productive assets (e.g., cattle) and durable (e.g., house) so that it is a form of saving. The reminder is used for their current household consumption. The stock of the parents' savings is non-liquid. Customary rights to exploit fertile lands and inherited houses in the village cannot be sold. Therefore, the migrant will enjoy them only if he returns home.

Assuming he plans to return, if he remits $r$ a migrant from type $i=h, l$ will consume $w^{m}(e)(1-r)$ in the first period and $r \alpha w^{m}(e)$ in the second period. His social status will be $s^{m}(e)$ in the first period and $s^{i}$ in the second. Let $\alpha^{i}(e)$ denotes the saving rate of parents $i=h, l$ for their child with education $e=0,1$. The child inter-temporal utility is:

$$
u^{i}(e)=(1-r) w^{m}(e) s^{m}(e)+r \alpha^{i}(e) w^{m}(e) s^{i}
$$

The next result unfolds.

Lemma 1. Individuals from caste $i=l, h$ with education $e=0,1$ remit the maximum and return home if the saving rate of their parents is higher than the threshold $\frac{s^{m}(e)}{s^{i}}(1-\underline{r})$. Otherwise, they never come back and remit the minimum $\underline{r}$.

Proof: See the appendix 7.1.

The all-or-nothing structure of the results of Lemma 1 comes from the convexity of individuals' preference over status and income. At first glance, this is surprising because convex preferences usually lead to balanced, interior solutions. However, the income/status complementarity implies that individuals' marginal utility of income increases with social status. All else being equal, a migrant would rather consume in the state of nature where his social status is highest. Since formally educated low castes have a higher social status abroad than at home, they would rather enjoy their consumption while abroad. ${ }^{23}$ This is different for children from the ruling caste, who never attended formal school; they have

\footnotetext{
${ }^{23}$ In particular if $s^{l}<s^{m}(1)(1-\underline{r})$ there is no saving rate that will compel them to remit.
} 
a higher status at home than abroad. ${ }^{24}$ For these uneducated migrants from the ruling caste, the decision to remit depends on the saving strategy of the parents. On the one hand, if their bequest is large enough they will return home to enjoy their retirement savings like the ruling caste. Following Bernheim et al. (1985), we will refer to this effect as "the strategic bequest motive". On the other hand, if their parents do not save enough, the uneducated migrants from the ruling caste would rather sever family ties and never return home in order to enjoy larger consumption levels. Finally, whether or not uneducated migrants from the low caste or formally educated migrants from the high caste remit large amounts hinges on the differential between their status at home and at destination. ${ }^{25}$

Since $s^{h}>s^{l}$ by assumption A1, Lemma 1 implies that the saving rate of low caste parents must be higher than the saving rate of the high caste parents if they wish to compel their children to remit large amounts: $\frac{s^{m}(e)}{s^{l}}>\frac{s^{m}(e)}{s^{h}}$. They are indeed obliged to compensate by a large bequest the humiliating status that their children will suffer if they return home. More interestingly, independently of their caste origin $i=l, h$, parents of formally educated children must save more than parents of children without such education: $\frac{s^{m}(1)}{s^{i}}>\frac{s^{m}(0)}{s^{i}}$. It is indeed harder to compel formally educated children to remit large amounts as their social status in the modern economy is higher than the social status of uneducated migrant workers. Formally educated migrant sons might thus consider to stay permanently abroad to enjoy higher levels of consumption. To avoid losing them in this way, their parents need to save more than parents of children who did not receive a formal education. As a result, the parents might enjoy lower consumption levels. To be more specific, let $r^{i}(e)$ be the share of the remittances that the parents can use for their consumption when they want to compel their migrant son to remit and return:

$$
r^{i}(e)=1-\frac{s^{m}(e)}{s^{i}}(1-\underline{r})
$$

\footnotetext{
${ }^{24}$ For the high caste children with education $e=0$ the necessary condition to make them remit is $\alpha^{h}(0) \geq \frac{s^{m}(0)}{s^{h}}(1-\underline{r})$, which is always possible as $s^{m}(0)<s^{h}$.

${ }^{25}$ It is impossible for the high caste (respectively low caste) parents of educated (respectively uneducated) child to make their offspring remit if $s^{i} \leq s^{m}(e)(1-\underline{r})$ with $(e=1, i=h)$ or $(e=0, i=l)$. Indeed, in this case $\frac{s^{m}(e)}{s^{i}} \geq 1-\underline{r}$ so that there is no saving rate that will compel them to return home.
} 
It is straightforward to check that $r^{l}(e)<r^{h}(e)$ and that $r^{i}(1)<r^{i}(0)$. Combining Lemma 1 with the optimal saving strategy of the parents, which depends on the value of $r^{i}(e)$ compared to $\underline{r}$, we establish a first result about the behavior of the migrant children.

Proposition 1. A child from caste $i=h, l$ with education $e=0,1$ returns home, and thus remits the maximum, if and only if $s^{m}(e) \leq s^{i}$.

Proof: See the appendix 7.2 .

Everything else being equal, low caste children remit less than high caste ones (i.e., $s^{l}<s^{h}$ ) and educated children remit less than children without any formal education (i.e., $\left.s^{m}(1)>s^{m}(0)\right)$. Since we observe family social status, migrants' education and remittance in our dataset, we will be able to assess the relevance of these predictions.

\subsection{Migration and Education}

In our database, there are on average 1.5 migrant sons per household, and both lowcaste and high-caste parents send their children abroad. In practice, the average returns to migration are sufficiently large to cover the cost of migration and the opportunity cost of local revenue loss. ${ }^{26}$ We thus focus on education choices made by parents who plan to send at least one of their children abroad.

The decision to send a child to school is made by the parents. If the child does not migrate, the parents do not have any incentive to prevent him from getting a formal education, provided there is a school nearby. The education decision becomes crucial to the family future earnings only when parents plan to have a child migrate. The next result provides the condition under which sending a future migrant child to a formal school is an equilibrium.

Proposition 2. Parents from caste $i=h, l$ send their future migrant children to the formal school if and only if $r^{i}(0) \leq \frac{w^{m}(1)}{w^{m}(0)} \max \left\{\underline{r}, r^{i}(1)\right\}$.

\footnotetext{
${ }^{26}$ To avoid introducing new notations both costs of sending a child abroad are here normalized to 0 and our model simply assumes that only one child per family migrates. This assumption is easily endogenized by introducing a fixed cost of migration (see appendix 7.3). The existence of this sunk cost, and of tight credit constraints explain that parents are limited in their ability to finance the migration of their children. It also explains that the children cannot migrate without the support of their family. They need the network of their relatives to settle down at destination. Without their support migrating is simply too expensive and risky.
} 
Proof: See the appendix 7.4

We have already established in Proposition 1 that those who will have the strongest incentives to remit are the uneducated children from the ruling caste. This suggests that, everything else being equal, parents from the high caste will send their future migrant children to a formal school less often than parents from the low caste. The next corollary formally establishes this result.

Corollary 1. If either $s^{m}(1) \geq s^{h}$ or $s^{m}(0) \geq s^{l}$ or $\underline{r} \geq \frac{s^{h}-s^{m}(1)}{s^{m}(1)-s^{l}} \frac{s^{l}-s^{m}(0)}{s^{m}(0)}$ then $e^{l *} \geq e^{h *}$.

Proof: See the appendix 7.5

The conditions in Corollary 1 are not too demanding. Basically, they require that $s^{m}(0)$ is not too low compared to $s^{l} \cdot{ }^{27}$ It depends of the cultural context under study. In the Matam region, the uneducated migrants are typically employed as cooks in restaurants. This occupation might not be the most prestigious one, yet it is not degrading. This is in contrast with the social status of a low caste in the village. N'Gaide (2003) lively illustrates the frustrations experienced by Haalpulaar slaves and artisans in the villages of the Senegal River valley for the offensive treatment they receive because they are repeatedly reminded of their low-status position in the village. In fact, historical accounts of the migration of "slaves", confirm the low status associated with the low caste in Senegal, even to the point where fighting in a war is a better option than staying and enduring humiliations linked with such social status (see Klein, 2005, and the history of the "Tirailleurs Sénégalais").

Corollary 1 establishes that parents from the low castes are more likely to send their future migrant child to a formal school than parents from the ruling caste. ${ }^{28}$ For the ruling caste, the decision to send a child to the formal school is costly: it reduces the child's incentive to return home, and thus his incentive to remit. He might as well develop his own savings plan and enjoy it at his migration destination. By contrast, the child will always come back if he has no formal education and his bequest is large enough. In this

\footnotetext{
${ }^{27}$ If $s^{m}(1) \geq s^{h}$, then corollary 1 holds. If $s^{m}(1)<s^{h}$ a sufficient condition for Corollary 1 to hold is $\frac{s^{h}-s^{m}(1)+\underline{r} s^{m}(0)}{s^{h}-s^{m}(1)+r s^{m}(1)} \leq \frac{s^{m}(0)}{s^{l}}$, which is true if $s^{m}(0)$ is not too low compared to $s^{l}$. In practice, if $s^{l}>s^{m}(0)$, then people from urban centers would try to retire in rural areas pretending they belong to the low caste (in order to enjoy a higher social prestige) instead of staying in town.

${ }^{28}$ For instance, if $s^{l} \leq s^{m}(0)<s^{m}(1)<s^{h}$ then parents from the low caste always send their future migrant child to formal school, while parents from the high caste prevent their future migrant child from attending formal school.
} 
case, the child will then remit the maximum possible amount. For the ruling caste, there are thus two opposite effects of formal schooling in this cultural context. While a higher formal education increases the probability of entering the modern sector and hence secure higher revenues, it also reduces the migrant incentive to come back.

In what follows, we assess the relevance of the theory by confronting its main predictions with our data from the Matam region in Senegal.

\section{The data and descriptive statistics}

The data come from a survey conducted by one of the authors in six villages around Matam, Senegal in Spring 2004. Initially, the survey was designed to address the issue of old-age support given by migrants to their fathers. Accordingly, all men above 64 years old - referred to as patriarchs - who had at least one son above 25 still alive, were surveyed. Information was gathered for 149 families at the level of the patriarch, his children, whether they live with him or not, and all household members. Data on 1765 permanent household members were collected, reflecting the impressive household sizes in this region, with an average of almost 12 members per household. ${ }^{29}$

Table 1 profiles the patriarchs by social status. As explained earlier in section 2.1, the Haalpulaar caste system is rather complex, however, the real prestige lies in the hand of the families who have exclusively access to political power: the ruling caste. Hence, for the purpose of the analysis it is sufficient to divide the sample in two status groups: the "high caste" or "ruling caste" and the rest, hence labeled "low caste".

In Table 1, it is striking to see that the ruling caste has significantly more migrant sons and they have themselves been significantly longer abroad (at the $10 \%$ level). Nevertheless, it is important to bear in mind that only patriarchs who have returned are taken into account here. According to the theory there could be a selection bias, as the migrant patriarchs from the low caste might have chosen not to return to avoid their local social stigma. This would explain the difference between the two groups. Indeed, $64 \%$ of the ruling caste patriarchs have migrated and returned while only $49 \%$ of the low caste did,

\footnotetext{
29 "Household" refers to an intergenerational family composed of the descendants of the patriarch who share meals together. For more details on the survey c.f. Demonsant (2008).
} 


\section{VARIABLES}

Age of the patriarch

Age when he left Koranic school

Household size

No. of adult sons

No. of (adult) sons currently abroad

$=1$ if the patriarch has been abroad

No. of years the patriarch spent abroad

Wealth index based on his inherited wealth

$=1$ if the father of the patriarch was born in the village

$=1$ if belongs to the ruling caste

\begin{tabular}{c|ccc}
$\begin{array}{c}\text { Total } \\
\mathrm{N}=146\end{array}$ & $\begin{array}{c}\text { The low caste } \\
\mathrm{N}=86\end{array}$ & $\begin{array}{c}\text { The ruling caste } \\
\mathrm{N}=60\end{array}$ & T-test \\
73.7 & 72.8 & 75.1 & $-2.13^{* *}$ \\
$(6.4)$ & $(6.2)$ & $(6.6)$ & \\
11.8 & 10.4 & 13.8 & $-2.54^{* *}$ \\
$(7.9)$ & $(8.3)$ & $(7.0)$ & \\
7.1 & 7.2 & 7.0 & 0.20 \\
$(3.4)$ & $(3.4)$ & $(3.6)$ & \\
3.2 & 3.1 & 3.5 & -1.18 \\
$(1.8)$ & $(1.8)$ & $(1.8)$ & \\
1.5 & 1.3 & 1.8 & $-1.95^{*}$ \\
$(1.5)$ & $(1.4)$ & $(1.7)$ & \\
$55 \%$ & $49 \%$ & $64 \%$ & $-1.83^{*}$ \\
& & & \\
9.8 & 8.3 & 12.0 & $-1.79^{*}$ \\
$(12.2)$ & $(11.9)$ & $(12.4)$ & \\
0.0 & -0.3 & 0.5 & $-3.55^{* * *}$ \\
$(1.5)$ & $(1.3)$ & $(1.6)$ & \\
$82 \%$ & $73 \%$ & $93 \%$ & $-3.16^{* * *}$ \\
$41 \%$ & & & \\
& & &
\end{tabular}

Notes: Standard errors in parentheses. Two-group mean-comparison t-test statistics are reported last column (* significant at $10 \%,{ }^{* *}$ at $5 \%$, and ${ }^{* * *}$ at $\left.1 \%\right)$.

Table 1: Profile of the patriarchs

and the difference in proportions between both groups (i.e., low caste vs. ruling elite) is statistically significant at the $10 \%$ level.

To measure the "initial wealth" an index based on the wealth inherited by the patriarch, including cattle and land received as inheritance along with the number of spouses of the patriarch's father. As expected, the ruling elite caste has a much higher inherited wealth index compared to non ruling castes, and the difference is significant at the $1 \%$ level. These differences are supported in the larger literature which also finds that the best and most productive lands are controlled by the ruling elite (Schmitz, 1994).

In line with what is expected from the status of the ruling caste, they are significantly older, more likely to be born in the village, and studied Koranic schools longer than those not in the ruling caste. It is important here to remember that all sampled patriarchs were on average born in the 30 's, when there was no formal primary schools in the region and therefore no alternative to Koranic studies. Only 28 out of 149 (19\%) reported they did 
not attend Koranic schools at all. ${ }^{30}$

In this paper, we will focus on the patriarch's adult sons (i.e., above 17 years old), which number 470 . This sample is not representative as they are descendants of patriarchs over 65 years old who are still alive. Yet, they are representative of the sons of elders who are key actors in gerontocratic village societies. Most had finished their schooling at the time of the survey (only 24 were still studying in the formal system and 16 in Koranic schools).

Table 2 displays their profile according to their status in the village and whether they were living in the village or abroad at the time of the survey: $45 \%$ of all adult sons were abroad (or in a Senegalese urban center). The fourth and the last columns show tstatistics of mean difference tests between the ruling caste and the low caste, and between non migrants and migrants, respectively.

The overall formal educational level is very low: 2.4 years of formal schooling on average for all adult sons. In the initial sample including both migrants and non migrants, there is no significant difference between the two castes with respect to formal schooling. What is striking, however, is the finding that migrants are significantly less likely (at the $10 \%$ level) to have been to a formal school than the non-migrants.

Turning to the sub-sample of migrant sons, Table 3 lists the descriptive statistics among the migrant sons testing significant mean differences depending on the social status and remittance choice. Starting with the remittance choice in our database, $62 \%$ of all migrants do remit regularly. Not surprisingly, the location of the migrant is crucial here, as amounts sent from another African country or Europe are not comparable. Remitters are hence more likely to have left the African continent (usually for Europe or the US), to have been abroad for a longer period, and to have a wife staying with their father (the wife and also children are preventing them from severing the ties with their village). More importantly for our analysis, they are more likely to belong to the ruling caste. Indeed, a central result that appears from the descriptive analysis along the social status divide,

\footnotetext{
${ }^{30}$ One legitimate concern here is that the ruling caste may have overestimated their Koranic studies as it is a sign of wisdom and a signal of their prestige. However, since this study focuses on formal education, the exact length of Koranic study is not important here. What counts is that the ruling caste values Koranic studies more than the low caste.
} 


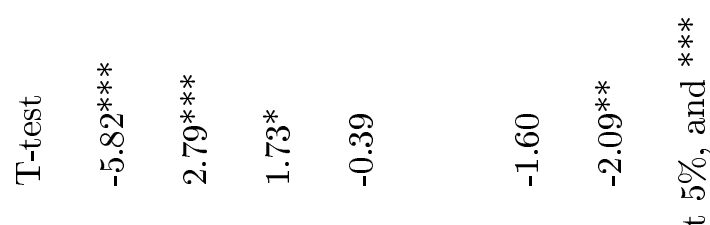

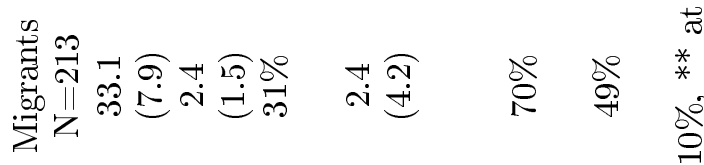

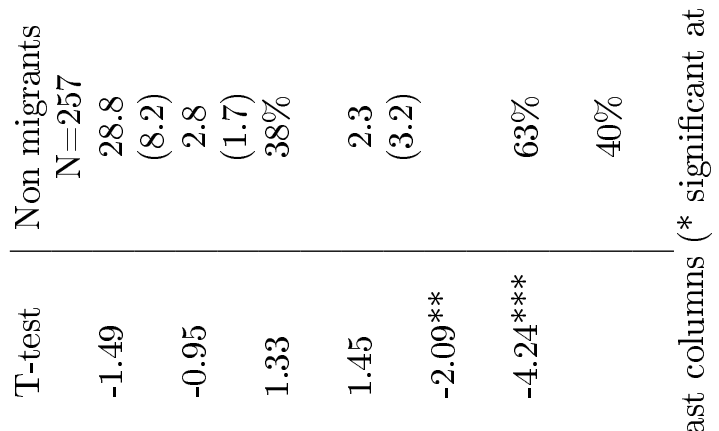

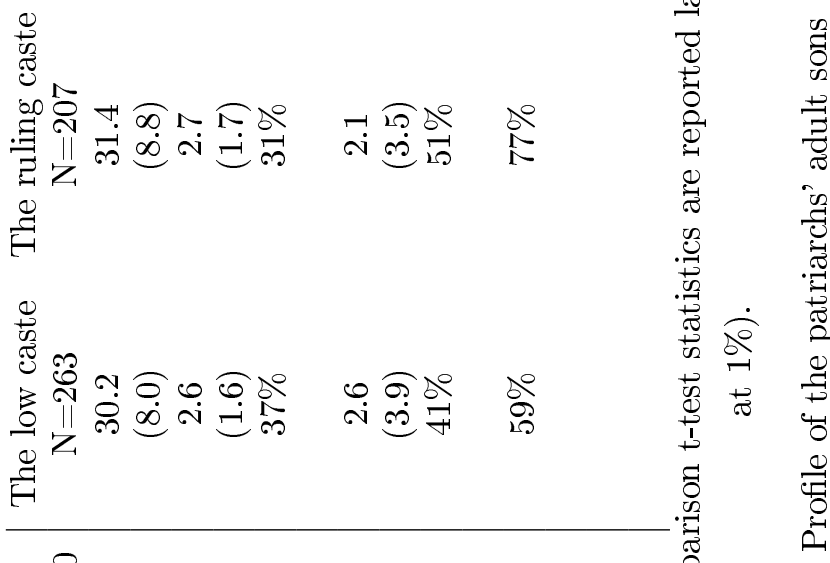

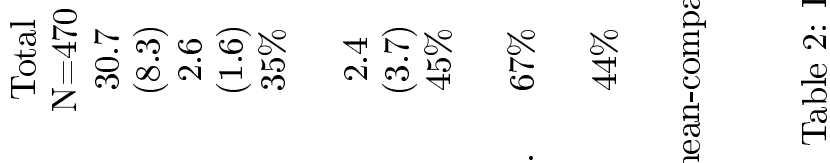

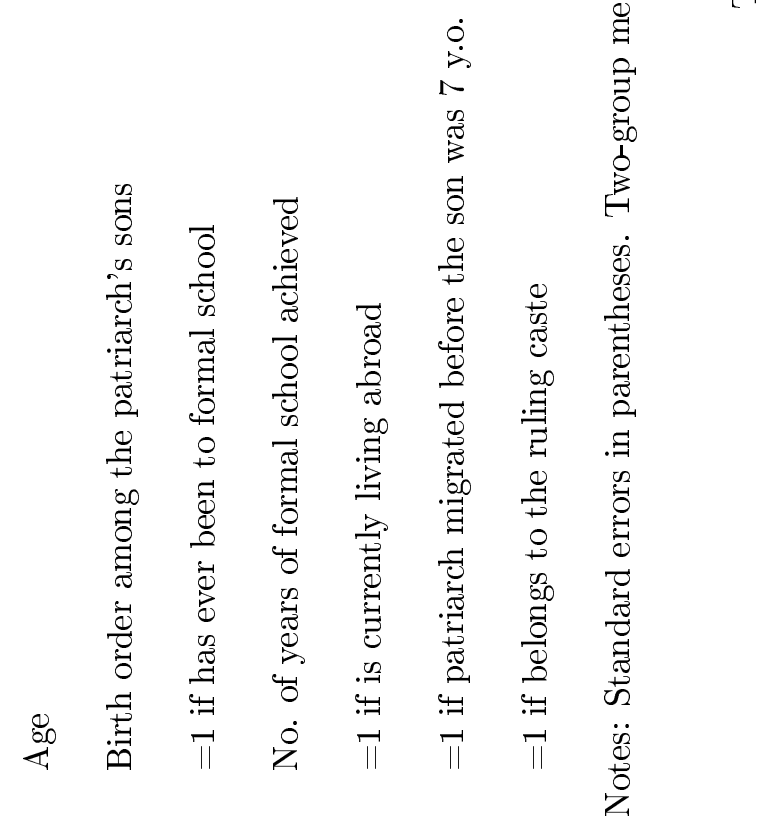




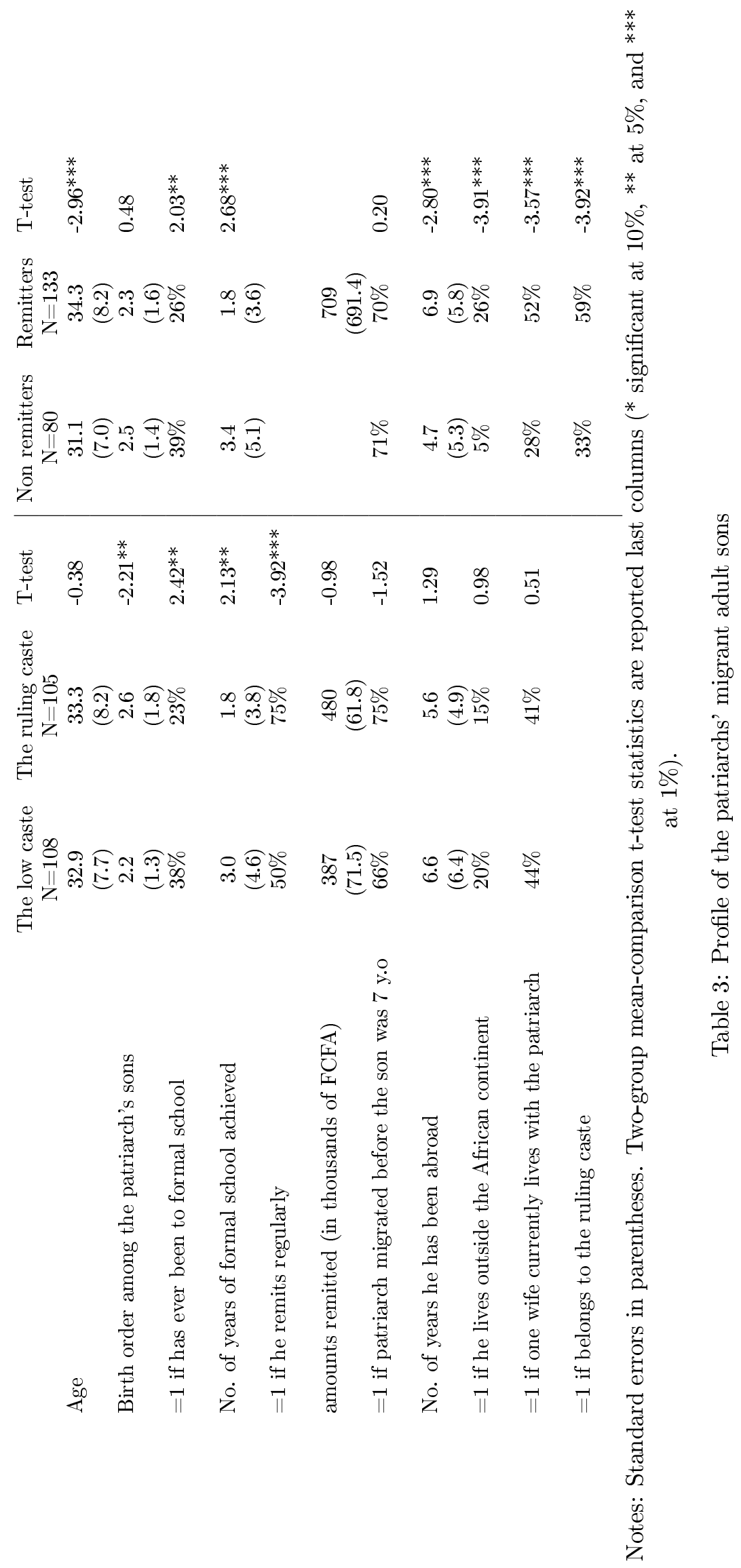


is that among migrants, those from the low caste have a significantly higher educational level than those of the ruling caste and yet remit significantly less regularly. ${ }^{31}$

Since migration destinations may be quite different in terms of returns to formal education, we would ideally like to study each migration destination separately. Educational levels at each destination are provided Table 8 in the appendix 7.6. These descriptive statistics confirm that the ruling caste and the low caste sons have distinct education profiles at each destination. For both castes, the ones who left the African continent have a much higher education level than non migrants. More strikingly, while non migrants from the ruling caste have a marginally higher education level than the low-caste ones, the education level of the low caste migrants is on average higher than the ruling caste for any destinations, while the difference is not always statistically significant due to the small sub-sample sizes.

The results of table 8 , along with the fact that the ruling caste is more likely to remit while remitters have a lower educational attainment than non-remitters, are in line with Lemma 1 and Proposition 2. We now turn to the econometric analysis to check their robustness. This empirical section does not constitute a formal test of the model developed in section 3 but rather shows consistent results with our theory. Moreover, despite the good fit of our regressions, the estimates below are still very much preliminary, given in particular, the small sample size. Conclusions from this study need to be qualified by this provision.

\section{The Empirical analysis}

Our empirical analysis relies on the sample of the patriarchs' adult sons. We will focus on education, migration and remittance decisions, since we observe all of those in our database. Unfortunately, although we can observe the effects of accumulated capital, we are unable to assess the effects of savings or investments in durables as we lack complete data and in particular the timing of the savings and of the investment made.

We start with the two predictions of Proposition 1 regarding remittance decision: children of lower castes remit less than children of the ruling caste, and children with

\footnotetext{
${ }^{31}$ Among the subset of those who remit, however, the amounts remitted are not statistically different between the low caste and the ruling caste.
} 
formal education remit less than children without any formal education.

\subsection{Results on remitting decision}

In this section, we focus on the subset of adult sons who had migrated at the time of the survey. We first examine which groups are more likely to remit. Results of the probit model are displayed column (1) in Table 4. We are specifically interested in whether sons from the ruling caste are ceteris paribus more likely to remit than sons from lower castes, and whether sons without formal education are more likely to remit than those with formal education. We also study the amount of remittances using Tobit model to account for the fact that $38 \%$ of migrant sons do not remit at all to their father. Tobit estimation results about the (log of) amounts remitted per year are displayed in column (2) in Table 4.

Table 4: Determinants of remitting behavior among the patriarchs' migrant sons

\begin{tabular}{|c|c|c|}
\hline & Remits regularly (probit) & Log remittances (tobit) \\
\hline & $\mathrm{N}=213$ & $\mathrm{~N}=210$ \\
\hline & $(1)$ & $(2)$ \\
\hline Age of the son & -0.0103 & -0.0544 \\
\hline & $(0.00640)$ & $(0.0446)$ \\
\hline No. of years of formal school achieved by the son & $-0.0376^{* * *}$ & $-0.293^{* * *}$ \\
\hline & $(0.0113)$ & $(0.0821)$ \\
\hline No. of years the son has been abroad & $0.0221^{* *}$ & $0.169^{* * *}$ \\
\hline & $(0.00908)$ & $(0.0588)$ \\
\hline$=1$ if the son lives outside the African continent & $0.407^{* * *}$ & $4.492^{* * *}$ \\
\hline & $(0.0582)$ & $(0.805)$ \\
\hline No. of the son's children living with the patriarch & $0.0667^{* *}$ & $0.331^{*}$ \\
\hline & $(0.0320)$ & $(0.171)$ \\
\hline Age of the patriarch & $0.0147^{* *}$ & $0.131^{* *}$ \\
\hline & $(0.00715)$ & $(0.0591)$ \\
\hline$=1$ if patriarch possesses land & $0.296^{* *}$ & $1.999^{*}$ \\
\hline & $(0.150)$ & $(1.083)$ \\
\hline$=1$ if belongs to the ruling caste & $0.253^{* * *}$ & $2.079^{* * *}$ \\
\hline & $(0.0884)$ & $(0.681)$ \\
\hline
\end{tabular}

Notes: Marginal effects for the probit model reported. For the tobit model, the dependent variable is the $\log$ of the amount remitted per year. Robust standard errors in parentheses; ${ }^{*}$ significant at $10 \%$; ${ }^{* *}$ at $5 \%$; $* * *$ at $1 \%$; Villages dummies are included, but not displayed.

For both the probability of remitting and the amount remitted, we find similar and 
consistent results. The son's age is not significant. The fact that the age of the patriarch has a significant positive effect for both the probit and the Tobit models, could reflect the greater needs of older patriarchs (e.g., in terms of health expenditure increasing with age).

The longer the son has been abroad, the higher the probability of remitting and the higher amounts sent to the patriarch. This shows how important time in area of destination is to securing employment and higher earnings. Migrants who succeeded in leaving the African continent (mainly to France) have also access to better jobs that are usually better paid increasing both the probability to regularly remit and the amounts remitted. Having children living in patriarch's home increases the probability of remitting and the amount remitted. This illustrates somehow what Cox (1987) calls "the exchange motive": remittances depend on the amount and cost of services provided to the migrant by those who stay behind. The primary service provided to the migrant is the care giving to the child left behind. It might also reflect an implicit "hostage" strategy, where the patriarch keeps the migrant's children to ensure that he will have incentives to return and to remit. ${ }^{32}$

The fact that the patriarch possesses land significantly increases both the probability of remitting and the amounts remitted. This effect reflects "the strategic bequest motive" illuminated in the theory: it is easier to make sons remit when there are illiquid assets (such as land) to inherit upon return. Migrants remit so that they can later claim their share of the inheritance. This result is identical to what Hoddinott (1992) found in rural Western Kenya.

The main results of these regressions regarding our model's predictions, are first, that sons from the ruling caste are both more likely to remit and remit higher amounts, and second, and perhaps more interestingly, the impact of schooling. It is found to be significantly negative on both the probability to remit and the amount sent. Although counter-intuitive at first sight, this result is consistent with the result of Proposition 1 and Lemma 1. It illustrates the trade-off faced by parents when they want to have a child

\footnotetext{
${ }^{32}$ Similarly, in a three-generation setting, Cox and Stark (1996) were the first ones to mention the "demonstration effect", where the parent takes good care of his own parents hoping that his own children who live with their grand-parents will do the same when time comes that he will retire.
} 
migrate. Formal education is a source of higher revenue but also of child emancipation. The main concern for the parents is to ensure that, once away from the village, their child will have the right incentives to remit. From this perspective, religious education is the best as it instills family values. Empirically, the income loss due to the lack of formal schooling is only of second order..$^{33}$

\subsection{Results on migration decision}

We ran probit models of the decision to have a child migrate by caste status testing different specifications. Results are displayed in Table 5.

Throughout all specifications and sub-samples, we found that older sons have a higher probability of migrating but their birth order and the patriarch's age have no significant impact. Running two separate regressions depending on whether the family belongs to the ruling caste, we found that both groups have different migration strategies. For the ruling caste, the patriarch's earlier migration impacts significantly and positively the probability of the son migrating, while the patriarch's longer Koranic studies decreases significantly the probability of his son migrating. The first result suggests that the migration of the patriarch may have permitted the accumulation of physical capital, which could have favored the son's migration. Concerning the second result on the patriarch's Koranic studies, all religious leaders belong to the ruling caste, so their sons will also pursue longer Koranic studies than the rest, which can delay their labor migration. ${ }^{34}$

Most importantly, we found that while a higher formal school level significantly increases the probability of migrating for the low caste, it is the reverse for the ruling caste: sons from the ruling caste without formal education have a higher probability of migrating. Hence, the regressions' results are consistent with the model predictions of Proposition 2. Ruling caste parents plan the migration of religiously educated sons, while those from lower castes plan the migration of formally educated sons instead. Pooling the data over the whole sample in columns (5) and (6), the contradictory impacts of formal

\footnotetext{
${ }^{33}$ These results are robust to the inclusion of additional controls such as the son's birth order, the patriarch's household size, the number of adult brothers abroad, and a wealth index based on the patriarch's inherited wealth. Those controls were removed however to favor a more parsimonious model better suited given the small sample size.

${ }^{34}$ Or possibly they will not migrate but instead dedicate to a Koranic master's career in their own village.
} 


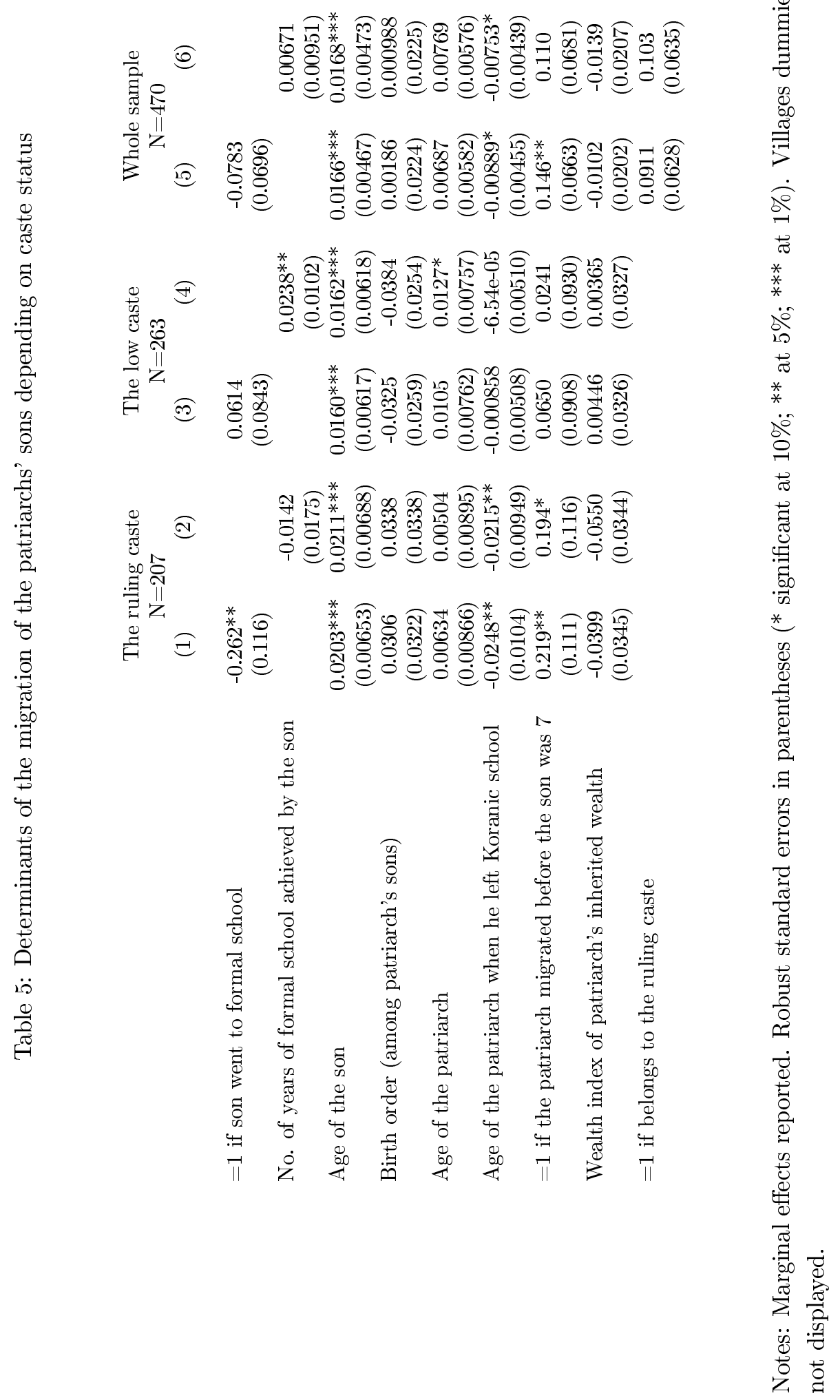


schooling on migration cancel each other out: it becomes not significant on the probability of migrating. Nor is there an effect of the caste of the family, which reflects the fact that both types of parents find it profitable to send a child abroad.

Nonetheless, these results need to be nuanced. As the theory suggests, education outcomes are endogenous to the migration decision: they are joined decisions. As a consequence, the results could be biased. ${ }^{35}$ Results from conditional logit estimations section 5.4 present an additional proof that higher formal education of ruling caste sons decreases their probability to migrate. But we will first turn to determinants of schooling decisions in details.

\subsection{Results on schooling decisions}

The main focus of the paper is to study the impact of migration prospect on educational choices in the Matam region. Accordingly, different specifications of the probit model of having attended formal school and the tobit model of formal school duration are displayed in Table 6 . The use of the tobit model is necessary to account for the high proportion of uneducated sons: $65 \%$ of adult sons have never been to a formal school.

In all three specifications of the probit models, empirical results suggest that the age and birth order of the son along with the age of the father, do not have a significant impact on either formal school attendance or number of years of formal school attended. The fact that the patriarch migrated before the son reached 7 years old has a consistently significant positive effect on both the probability of formal school attendance and number of years attended. This can be interpreted in two ways. Either it is an income effect showing that the family could afford the opportunity cost of schooling, or it is the "brain gain" effect described earlier: while abroad, the patriarch realized the importance of formal schooling. Concerning wealth effect, to avoid any simultaneity bias, a wealth index based on the patriarch's own bequest is introduced. It shows that wealthier families are more likely to send their children to a formal school. However, when patriarch's Koranic school years is introduced it becomes non-significant, and it has also no significant impact on the number of years of formal schooling.

\footnotetext{
${ }^{35}$ We report in Appendix 7.7 estimations correcting for the endogeneity of education in the migration equation. However, the IV estimates of education outcomes are no longer significant, which is most likely due to the poor predictive power of the instrument.
} 


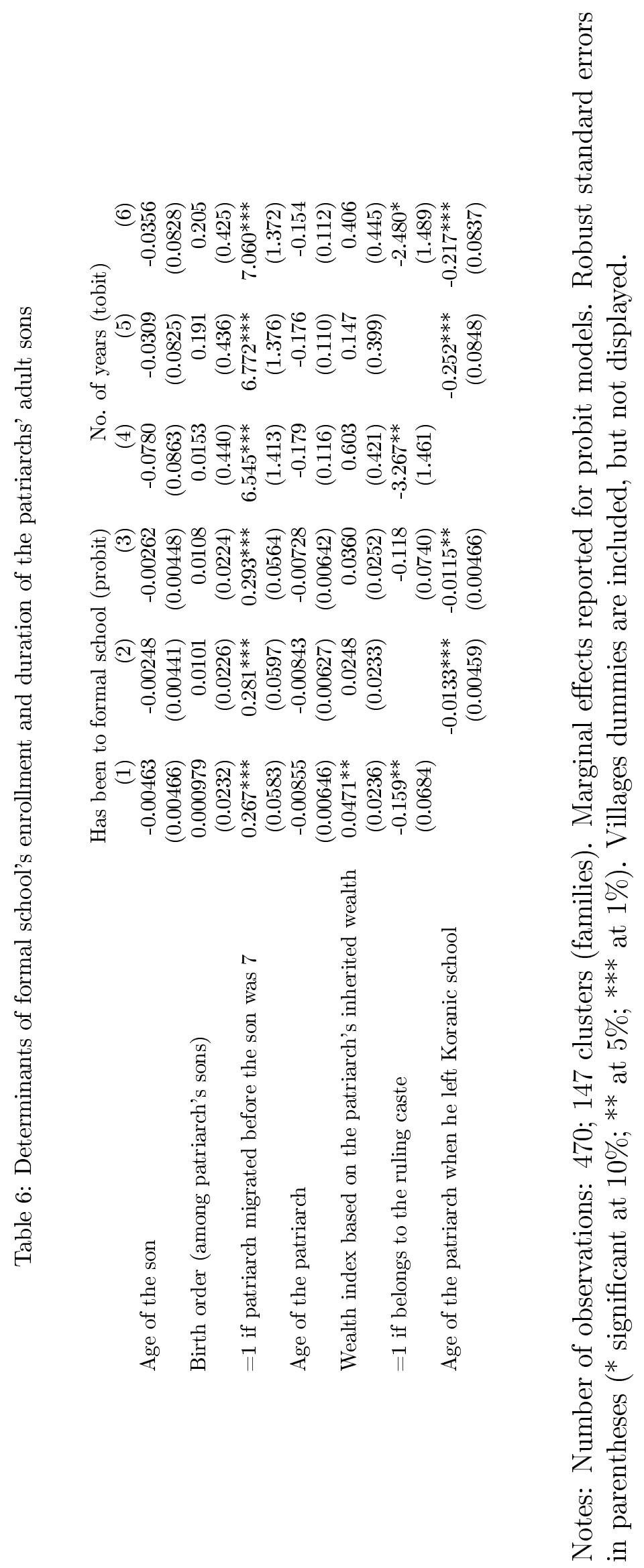


Especially interesting from the theoretical perspective, is the finding that ruling caste families are less likely than lower castes to send their children to formal school and send them fewer years. Similarly, the number of years the patriarch has studied Koran has a significant negative impact on the probability of having attended formal school and the number of years. This is hardly surprising as the local power of the ruling caste is related to religious achievement. ${ }^{36}$ Thus, the introduction of the patriarch's Koranic studies lowers the significance of the ruling caste dummy: when both are introduced, the sign of the ruling caste dummy is still negative but it becomes marginally non significant (i.e., it is almost significant at the $10 \%$ level) for the probability of having attended formal school, while it remains significant but of lower impact for the number of years of formal schooling.

These results are consistent with those offered in Proposition 2. However, we could also entertain alternative explanations. Perhaps the schooling choices of the ruling class reflect their more traditional world view that emphasizes local culture and reproduction of the social structure of Matam society. Conversely, lower castes may seek a more modern perspective that encourages outmigration and broader opportunities structures. To assess the different explanations for alternative parental education decisions, we examine the education choices of the migrant and non-migrant sons of each caste. If cultural values and social norms shape these choices, there should not be any variation in the educational choices of migrants and non-migrants. In fact, if any difference appears, it should be in favor of formal education for the future migrants as it has a higher return for them. By contrast, if moral hazard issues shape education choices, we should expect different choices for the future migrants and for their non-migrant siblings. Not all children of the ruling caste would be less likely to attend formal schools, only those that parents plan to send abroad.

Recall from the descriptive statistics that migrant sons of the ruling caste are significatively less likely to attend formal school compared to their lower caste counterparts and, when they do, their years of formal schooling are also significatively fewer than those

\footnotetext{
${ }^{36}$ Indeed, there is a very high correlation between both variables in our data. As we saw in Table 1 , patriarchs from the ruling caste remained in Koranic school three years more than patriarchs from other castes and this difference is significant at the $5 \%$ level.
} 
of sons of lower castes (see Table 3). Yet in the initial sample of both migrants and non-migrants, the difference in formal schooling outcomes is not statistically significant between sons of both castes (see Table 2). This important result highlights the deliberate strategy of the ruling caste parents; they tend to choose not to send their prospective migrant sons to a formal school, but they are as likely as lower caste parents to send their non migrant sons to one.

The following section shows the robustness of these results controlling for unobserved family heterogeneity.

\subsection{Who migrates within families?}

In Table 7 we estimate the determinants of the migration decisions in the family. Are formally educated sons within families from the ruling elite less likely to migrate?

The proper way to model this is to use conditional logit models, i.e., using family fixed effects. A caveat of the conditional logit is that all observations with the same outcome for the dependent variable are excluded from the estimation. For this reason our already small sample size fall dramatically by about $50 \%$ of the original size to 128 (instead of the original 207 sons from the ruling elite). Similarly, no family invariant variable can be introduced in the model specification.

Despite these limitations, these regressions give credit to our hypothesis: without additional controls, the impact of having attended formal school is negative and significant at the $10 \%$ level. In other words, patriarchs from the ruling caste tend to send in priority their uneducated son abroad. Introducing the age and birth order of the son along with a dummy to control whether the patriarch had already migrated when the son was 7 years old, does not affect the sign. However, the significance level of having attended formal school raises to the marginally significant level of $12.5 \%$. The small sample size explains this lower significance result compared to the full sample. All the more, the families who perfectly fit our model were dropped from the estimation sample (e.g., all ruling caste families who send only uneducated sons abroad and all low caste who send only educated sons). As a consequence, this tends to reduce the impact of schooling variables on migration decisions, which reflects in our estimation in marginally significant parameters. 


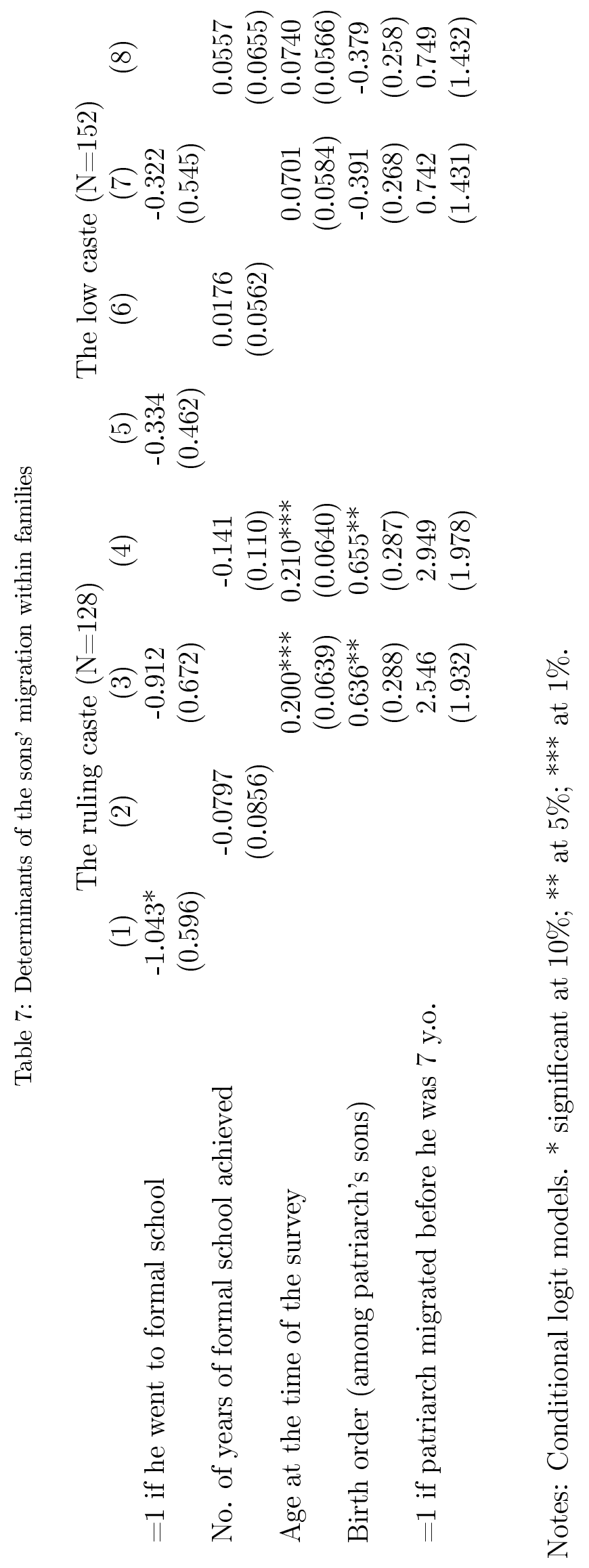




\section{Conclusion}

In a hierarchical society where members are stratified by caste and social mobility is restricted, motivations to migrate are shaped by caste identity. On the one hand, low caste migrants may be looking for the anonymity of the big city or a foreign country to shed their social stigmas. On the other hand, high caste migrants may be looking for increased earnings to remit in order to maintain their social ranking with expectations of returning. In this context, what would be the schooling strategy of each group?

Introducing in the utility function the social status along with the revenue, we were able to replicate what was observed in the Matam region of Senegal. The model describes the strategic choices parents make regarding the educational and migration careers of their sons. It shows how it is optimal for high caste parents not to send to a formal school the sons they plan to send abroad. Indeed, those uneducated migrants from the ruling caste experience a significant loss of prestige when they migrate. Moreover, receiving a Koranic education strengthens their position in the village, and hence their willingness to come back and thus remit. In contrast, migrants from lower castes receive social recognition through migration, especially if they have received a formal education prior to migration.

This study gives additional support in favor of getting rid of an obsolete caste mentality in such a context. It is an additional barrier to the formal education of high caste children. Migration can play an effective role in local development through the return of skilled migrants. Yet in our context, not only the best educated low caste sons will contribute to the "brain drain" affecting the potential development of the region, but also the ruling caste prevents the achievement of universal primary education. Examining this mechanism closely reveals that the absence of a developed social security system (e.g., a reliable pension system) hinders development. It is indeed the need of the ruling elite to rely on their sons which impedes parents to send them to a formal school. 


\section{Appendix}

\subsection{Proof of Lemma 1:}

The migrant needs to consider two cases. First, given his education, if he migrates and does not return (i.e., $R=0$ ) the agent $i=h, l$ will get status $s^{m}(e)$ and income $w^{m}(e)$ in his productive period, that he can spread as he wishes between adulthood and retirement. If he remits $r$ and saves $\tau$ he will consume $w^{m}(e)(1-r)(1-\tau)$ in the first period and $w^{m}(e)(1-r) \tau$ in the second period. Since his social status will be the same in both periods his inter-temporal utility is $u^{i}(e)=s^{m}(e)\left(w^{m}(e)(1-r)(1-\tau)+w^{m}(e)(1-r) \tau\right)$. In the end he maximizes with respect to the remittance rate $r: u^{i}(r)=w^{m}(e) s^{m}(e)(1-r)$. This is a decreasing function of $r$, so that an agent who does not plan to return will remit the minimum $\underline{r}$.

Second, if he migrates and plans to return, he will remit. Otherwise, he will not be welcome home upon return. Remittances are a key instrument to maintain the family social status and his future influence in the village. Moreover, remittances represent his retirement plan in case of return. If he remits, a share $\alpha \in[0,1]$ of the remittance is invested by his parents in durables and productive assets. The migrant will enjoy them only if he returns home. As a result, if he remits $r$ a migrant from type $i=h, l$ will consume $w^{m}(e)(1-r)$ in the first period and $r \alpha w^{m}(e)$ in the second period. His social status will be $s^{m}(e)$ in the first period and $s^{i}$ in the second. Let $\alpha^{i}(e)$ denotes the saving rate of parents $i=h, l$ for their child with education $e=0,1$. After actualization, the child inter-temporal utility is given by (2). Since (2) is linear in $r$, if he plans to come back, he remits the maximum $r=1$, so that his expected utility is $\alpha^{i}(e) w^{m}(e) s^{i}$. Moreover, since the minimum value of remittance is $\underline{r}$, we deduce that if the child chooses not to come back, his utility is $(1-\underline{r}) w^{m}(e) s^{m}(e)$. We deduce that if $\alpha^{i}(e) w^{m}(e) s^{i} \geq(1-\underline{r}) w^{m}(e) s^{m}(e)$, then $r^{i}=1$, if $\alpha^{i}(e) s^{i}<(1-\underline{r}) s^{m}(e)$, then $r^{i}=\underline{r}$. Lemma 1 follows. QED 


\subsection{Proof of Proposition 1}

We first study, for caste $i=h, l$, the parents' incentive to save for their migrant child. They have, depending on $e \in\{0,1\}$, the following utility with respect to saving ratio $\alpha$ :

$$
u_{e}^{i}(\alpha)=s^{i} w^{m}(e) \begin{cases}1-\alpha & \text { if } \alpha \geq \frac{s^{m}(e)}{s^{i}}(1-\underline{r}) \\ \underline{r}(1-\alpha) & \text { otherwise }\end{cases}
$$

Both terms in equation (4) are decreasing in $\alpha$. To maximize the utility in the first case, parents need to save the minimum value compatible with the remittance incentive constraint of the children, $\alpha^{i}(e)=\frac{s^{m}(e)}{s^{i}}(1-\underline{r})$. By contrast, in the second case they choose 0 . The optimal choice between saving or not saving depends on the share of the remittance that the parents can use for their consumption, $r^{i}(e)=1-\frac{s^{m}(e)}{s^{i}}(1-\underline{r})$ compared to $\underline{r}$. We deduce that parents from caste $i=h, l$ with children with education $e \in\{0,1\}$ are saving at rate

$$
\alpha^{i}(e)= \begin{cases}\frac{s^{m}(e)}{s^{i}}(1-\underline{r}) & \text { if } s^{i}>s^{m}(e) \\ 0 & \text { otherwise }\end{cases}
$$

Combining Lemma 1 with equation (5) yields Proposition 1.QED

\subsection{Decision to have a child migrate: robustness to the introduction of migration cost}

This section aims to show the robustness of the results to the introduction of migration costs. We focus here on the fixed cost of migration, but the results are similarly robust to the introduction of an opportunity cost of migration in the form of a forgone local revenue for the migrant child. Let $F>0$ denote the fixed cost of migration. The parents will finance their child's migration if they expect a return larger than the cost. We first show the following Lemma.

Lemma 2. Let $r^{i}(e)$ be defined by equation (3). Parents of caste $i=l, h$ choose to have a child with education $e=0,1$ migrate if and only if $\frac{F}{w^{m}(e)} \leq \max \left\{\underline{r}, r^{i}(e)\right\}$.

To prove it, let us start with the case $\underline{r} \geq r^{i}(e)$ where $r^{i}(e)$ is defined by equation (3). This inequality is equivalent to $s^{i} \leq s^{m}(e)$. By virtue of Proposition 1 , the children from caste $i=l, h$ with education $e=0,1$ will not return. As a result, they will remit the 
minimum $\underline{r}$. The parents have the following expected utility depending on whether they have their child with education $e=0,1$ migrate, $m=1$ or not, $m=0$ :

$$
u^{i}(m) / s^{i}=m\left[w^{m}(e) \underline{r}-F\right] \quad i=h, l \quad e=0,1
$$

We deduce from equation (6) that the parents from caste $i$ choose to have their child with education $e$ migrate if and only if $w^{m}(e) \underline{r}>F$.

Next, we turn to $\underline{r}<r^{i}(e)$ which implies $s^{i}>s^{m}(e)$. By virtue of Proposition 1 , the child will then return and remit the maximum, so that the parents' utility is:

$$
u_{e}^{i}(m) / s^{i}=m\left(r^{i}(e) w^{m}(e)-F\right)
$$

We deduce that it is optimal for the parents from caste $i=h, l$ to have their child with education $e=0,1$ migrate if and only if $r^{i}(e) w^{m}(e)>F$. Since $\underline{r}>r^{i}(e)$, whenever $s^{i} \leq s^{m}(e)$, we deduce that $m=1$ whenever $F \leq \max \left\{\underline{r}, r^{i}(e)\right\} w^{m}(e)$, which completes the proof of Lemma 2.

By assumption A2, $w^{m}(1) \underline{r}>w^{m}(0) \underline{r}$, so that the migration condition is easier to meet for formally educated children. We deduce that each type of parents, $i=h, l$, might find profitable to have a child migrate if the following condition holds:

$$
F<w^{m}(0) \underline{r} .
$$

The interpretation of this condition is that, when the level of the fixed migration cost is not too large compared to the minimum remittance, it is always worthwhile to have a child migrate, even if he should never return. To simplify the exposition in the main text we simply set $F=0$ and assume that one child migrates per family. QED

\subsection{Proof of Proposition 2}

We study education decision by parents from caste $i=h, l$. Let $r^{i}(e)$ be defined by equation (3) so that $r^{i}(1)<r^{i}(0)$ for $i=l, h$.

First, if $r^{i}(0) \leq \underline{r}$, which is equivalent to $s^{i} \leq s^{m}(0)$, whether the child is educated or not does not affect the remittance rate which will always be minimum: $\underline{r}$. Then, the 
expected return to migration is $\underline{r} w(e)$. Since $w(1)>w(0)$, if the child migrates it is optimal to send him to a formal school to receive higher expected remittances.

Second, if $r^{i}(1) \leq \underline{r}<r^{i}(0)$, which is equivalent to $s^{m}(0)<s^{i} \leq s^{m}(1)$, then a child without formal education remits the maximum, while a child with a formal education remits the minimum. We thus need to compare the income of the parents when $e=1$, $w^{m}(1) \underline{r}$, with their income when $e=0, w^{m}(0) r^{i}(0)$. We deduce that it is optimal for the parents to send a child to a formal school if and only if $w^{m}(0) r^{i}(0) \leq \underline{r} w^{m}(1)$.

Third, if $\underline{r}<r^{i}(1)$, which is equivalent to $s^{m}(1)<s^{i}$, Proposition 1 implies that whether the child is educated or not does not affect the remittance rate which will always be the maximum. We deduce that it is optimal for the parents to send a child to a formal school if and only if $w^{m}(0) r^{i}(0) \leq r^{i}(1) w^{m}(1)$.

Aggregating the three cases together, we obtain that formal education is the optimal choice if and only if $r^{i}(0) w^{m}(0) \leq w^{m}(1) \max \left\{\underline{r}, r^{i}(1)\right\}$ which is the condition of Proposition 2. QED

\subsection{Proof of Corollary 1}

We now turn to the proof that parents from the low caste are more likely to send their future migrant child to a formal school than parents from the ruling caste: $e^{l *} \geq e^{h *}$. The assumption $s^{m}(1)>s^{l}$ in A1 implies in (3) that $r^{l}(1)<\underline{r}$. For the low caste, $\max \left\{r^{l}(1), \underline{r}\right\}=\underline{r}$, so that the condition in Proposition 2 is $r^{l}(0) \leq \frac{w^{m}(1)}{w^{m}(0)} \underline{r}$. For the high caste, we need to consider two cases. First, if $s^{m}(1) \geq s^{h}$ then the condition is $r^{h}(0) \leq \frac{w^{m}(1)}{w^{m}(0)} \underline{r}$. Since $s^{l}<s^{h}$ implies $r^{l}(0)<r^{h}(0)$, we deduce that $e^{l *} \geq e^{h *}$.

Second, if $s^{m}(1)<s^{h}$ then the condition is $r^{h}(0) \leq \frac{w^{m}(1)}{w^{m}(0)} r^{h}(1)$. We thus need to compare $\frac{r}{r^{l}(0)}$ with $\frac{r^{h}(1)}{r^{h}(0)}$. We want to establish that $\frac{r}{r^{l}(0)} \geq \frac{r^{h}(1)}{r^{h}(0)}$, which is equivalent to $\underline{r} s^{m}(0)\left(s^{m}(1)-s^{l}\right) \geq\left(s^{h}-s^{m}(1)\right)\left(s^{l}-s^{m}(0)\right)$. The left hand side is always positive by assumption A1. The first parenthesis in the right hand side is positive by assumption (we are studying the case $s^{m}(1)<s^{h}$ ). We deduce that if either $s^{l} \leq s^{m}(0)$ or $\underline{r} \geq$ $\frac{s^{h}-s^{m}(1)}{s^{m}(1)-s^{l}} \frac{s^{l}-s^{m}(0)}{s^{m}(0)}$, then $e^{l *} \geq e^{h *}$. QED

\subsection{Education levels by destinations}

Migration destinations have been regrouped in three major ones, reported namely "Dakar", "other African countries" and "outside the African continent". The first des- 
tination, "Dakar", refers more precisely to all domestic destinations (mostly Dakar) but also includes all adjacent countries, namely Mauritania, Mali, Gambia and Guinea, where the use of vernaculars could still prove useful (i.e., Pulaar and Wolof are widely spoken in those countries). The second destination, "other African" refers to the rest of African countries. In our data Gabon, Congo, Côte d'Ivoire and Cameroon represent $85 \%$ of these destinations. Finally, "outside the African continent" refers mostly to France (almost $70 \%$ of the cases) but also USA, Italy and Spain.

Table 8 is suggestive that low-caste migrants have higher education levels than nonmigrants for any destination, while the difference is not always statistically significant due to the small sample sizes. Only the other African destination yields a significant difference in education levels between the low caste and the ruling caste. For the ruling caste, we even observe lower education levels for migrants in Dakar (not statistically significant) and in other African destinations (significant at 1\%) in comparison to non migrants. For both castes, the ones who left the African continent have a much higher education level than non migrants (resulting in significant t-tests resp. at the $10 \%$ and $1 \%$ for the ruling caste and the low caste). Still, while non migrants from the ruling caste have a slightly (and not statistically significant) higher education level than the low-caste ones, what is striking is that the education levels of the low caste are on average higher than the ruling caste for any destinations, the t-tests being however significant for the other African destination only.

The fact that the ruling caste migrants in the Other African destinations have much lower education levels that all the rest could make us believe that they represent an unusual sample, who drive the results. Table 9 shows us that except for education levels, the profile of ruling caste migrants in other African countries are identical to all ruling caste migrants as far as observables are concerned. ${ }^{37}$ One exception being the number of migrant's children who live with the patriarch: they have significantly fewer children residing with the patriarch. This might reflect an "exchange motive" (or a "demonstration effect") or

\footnotetext{
${ }^{37}$ The most important unobservables are the migrant's occupation and salary. However this information is not reliable when asked to a family member who stayed behind as she may not know it or not want to reveal it. Indeed, the occupations abroad are usually not prestigious so asking someone what is job is abroad is hence taboo (even within the family).
} 


$\begin{array}{lccccccc} & \text { Non migrants } & \text { Dakar } & \text { T-test } & \text { Other African } & \text { T-test } & \text { Europe } & \text { T-test } \\ \text { For the ruling caste } & 2.35 & 2.28 & -0.12 & 0.43 & -3.76^{* * *} & 4.06 & 1.79^{*} \\ & (3.19) & (4.17) & & (1.38) & & (5.33) & \\ & \mathrm{N}=102 & \mathrm{~N}=47 & & \mathrm{~N}=42 & & \mathrm{~N}=16 & \\ \text { For the low-caste } & 2.25 & 2.69 & 0.74 & 2.27 & 0.02 & 5.09 & 3.42^{* * *} \\ & (3.25) & (4.47) & & (3.75) & & (5.71) & \\ \text { T-test by caste } & \mathrm{N}=155 & \mathrm{~N}=49 & \mathrm{~N}=37 & & \mathrm{~N}=22 & \\ & -0.23 & 0.47 & & 2.96^{* * *} & & 0.56\end{array}$

Notes: Standard deviations are in parenthesis. "Dakar" refers to Dakar and neighboring countries. In columns 3,5 and 7 are reported two-group mean-comparison t-test statistics between each respective destination's migrants and non migrants. The last line reports two-group mean-comparison t-test statistics between the low and ruling castes (* significant at $10 \%, * *$ at $5 \%$, and $* * *$ at $1 \%$ ).

Table 8: Mean years of formal schooling by destinations and castes

even a "hostage strategy" developed by the parents of educated children who are sent further away. The analysis indeed shows that having children leaving with the patriarch increases the likelihood of remittances. It helps counteracting the disincentive to remit of a higher education. This suggests that the two instruments "formal education" and "keeping the migrant children in the village" are complement for the parents. Anyways, since it matters for the remittance decision, we control for the number of children left behind as this variable is included in the remitting regression.

\subsection{Instrumenting schooling in the migration equation}

Potential candidates for instruments for schooling are very few. The supply in education is the first thing that comes to mind, as possibly correlated with school attendance rate and uncorrelated with migration rate, except via schooling. In the six villages surveyed, a first (formal) primary school opened between 1961 and 1998. Obviously, if a primary school opens nearby after you completed primary school it will not have any impact on your schooling. After testing various ages at which a first primary school opening in the village induce higher school attendance, we found that school opening before birth yields greater significance level for the impact on schooling decision.

Hence, Table 10 displays the first stage of the estimation validating the instrument for the ruling elite only. For this reason, we wont be able to perform such analysis on the low caste sample. Following Evans and Schwab (1995), the proper way to estimate 


\begin{tabular}{|c|c|c|c|}
\hline & $\begin{array}{l}\text { In other African countries } \\
\qquad \mathrm{N}=42\end{array}$ & $\begin{array}{l}\text { In other destinations } \\
\qquad \mathrm{N}=63\end{array}$ & T-test \\
\hline Age & $\begin{array}{l}32.5 \\
(8.0)\end{array}$ & $\begin{array}{l}33.9 \\
(8.4)\end{array}$ & 0.90 \\
\hline Birth order among the patriarch's sons & $\begin{array}{c}2.6 \\
(1.5)\end{array}$ & $\begin{array}{c}2.7 \\
(1.9)\end{array}$ & 0.23 \\
\hline$=1$ if has ever been to formal school & $9 \%$ & $32 \%$ & $2.72^{* * *}$ \\
\hline No. of years of formal school achieved & $\begin{array}{c}0.4 \\
(1.4)\end{array}$ & $\begin{array}{c}2.7 \\
(4.5)\end{array}$ & $3.20^{* * *}$ \\
\hline$=1$ if he remits regularly & $81 \%$ & $71 \%$ & -1.10 \\
\hline Amounts remitted (in thousands of FCFA) & $\begin{array}{c}423 \\
(380)\end{array}$ & $\begin{array}{c}525 \\
(756)\end{array}$ & 0.80 \\
\hline Age of the patriarch & $\begin{array}{l}75.8 \\
(5.2)\end{array}$ & $\begin{array}{l}76.5 \\
(6.5)\end{array}$ & 0.63 \\
\hline$=1$ if patriarch migrated before the son was 7 y.o & $69 \%$ & $79 \%$ & 1.20 \\
\hline No. of years he has been abroad & $\begin{array}{c}5.8 \\
(4.8)\end{array}$ & $\begin{array}{c}5.4 \\
(5.0)\end{array}$ & -0.38 \\
\hline$=1$ if one wife currently lives with the patriarch & $33 \%$ & $44 \%$ & 0.26 \\
\hline No. of children living with patriarch & 0.7 & 1.53 & $2.15^{* *}$ \\
\hline
\end{tabular}

Notes: Standard errors in parentheses. Two-group mean-comparison t-test statistics are reported last column (* significant at $10 \%,{ }^{* *}$ at $5 \%$, and ${ }^{* * *}$ at $\left.1 \%\right)$.

Table 9: Profile of the ruling caste migrants: comparing other African countries to all other destinations

a probit model with a discrete endogenous regressor is the seemingly unrelated (SUR) biprobit model. As a benchmark, we also run an "ivprobit" which handles probit models with endogenous regressors, and a 2SLS considering both dichotomous migration and schooling decisions as continuous variables (e.g., using a linear probability model). All the results are displayed in Table 11.

For all estimation procedures, the impact of the instrumented schooling variable is negative but no longer significant. This could indicate that once instrumented education does not affect migration anymore. Still, this result is consistent with the Proposition 2 derived from our model: parents from the ruling caste do not seem to send their future migrant sons to formal school. Nevertheless, this result could simply be a consequence of the poor predictive power of the instrument for schooling. The absence of other instruments prevents from being able to test the validity of the instrument. The problem we are facing seems to be that IV estimation are less precise.

Nevertheless, taking advantage of the fact that most patriarchs have various adult 


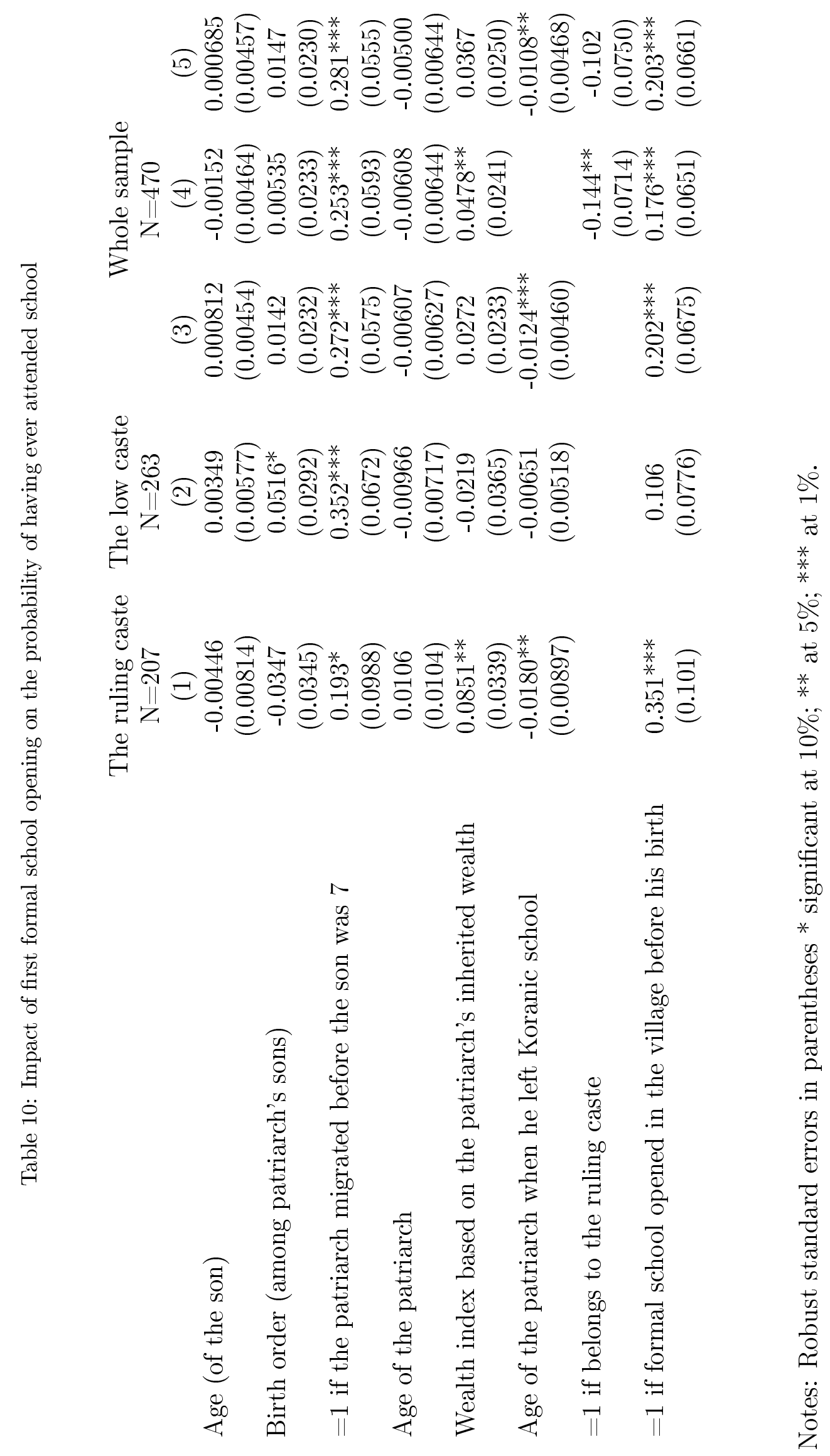


Table 11: Impact of schooling on the probability to migrate of the ruling caste correcting endogeneity

$\begin{array}{lccc} & (1) & (2) & (3) \\ =1 \text { if son went to formal school } & -0.353 & -0.155 & -0.401 \\ & (0.765) & (0.265) & (0.695) \\ \text { Age of the son } & 0.0470^{* * *} & 0.0164^{* * *} & 0.047^{* * *} \\ & (0.0159) & (0.00543) & (0.016) \\ \text { Birth order (among patriarch's sons) } & 0.0839 & 0.0304 & 0.083 \\ & (0.0824) & (0.0270) & (0.082) \\ =1 \text { if the patriarch migrated before the son was } 7 & 0.483 & 0.173 & 0.495 \\ & (0.326) & (0.109) & (0.306) \\ \text { Age of the patriarch } & 0.0165 & 0.00603 & 0.017 \\ & (0.0233) & (0.00814) & (0.023) \\ \text { Age of the patriarch when he left Koranic school } & -0.0612^{* *} & -0.0216^{* *} & -0.062^{* *} \\ & (0.0264) & (0.00853) & (0.026) \\ \text { Wealth index of patriarch's inherited wealth } & -0.0979 & -0.0327 & -0.094 \\ & (0.0965) & (0.0342) & (0.091)\end{array}$

Notes: Standard errors in parentheses. IVprobit is used in column (1), 2SLS regression in column (2), while results of bivariate probit for the migration equation is shown in column (3), using school opening before birth as instrument. (* significant at $10 \%,{ }^{* *}$ at $5 \%$, and $* * *$ at $1 \%$ ).

sons each can help us get around the endogeneity issue and provide more robust results. Results of conditional logit are shown in section 5.4. 


\section{References}

Akerlof, G., 1976. The economics of caste and of the rat race and other woeful tales. The Quaterly Journal of Economics 90, 599-617.

Alcaraz, C., Chiquiar, D., Salcedo, A., 2012. Remittances, schooling, and child labor in Mexico. The Journal of Development Economics 97, 156-165.

Amelewonou, K., Brossard, M., Reuge, N., 2003. Atteindre la scolarisation primaire universelle au Sénégal. eléments d'analyse de la rétention. Pôle de Dakar. Note d'Analyse.

André, P., Demonsant, J.L., 2009. Koranic schools in Senegal : A real barrier to formal education ? Universidad de Guanajuato, Department of Economics and Finance Worping Paper EM200901.

Antman, F., 2011. The intergenerational effects of paternal migration on schooling and work: What can we learn from children's time allocations? The Journal of Development Economics 96, 200-208.

Auriol, E., Renault, R., 2002. Incentive hierarchies. Annales d'Economie et de Statistique 63-64, 261-282.

Auriol, E., Renault, R., 2008. Status and incentives. RAND Journal of Economics 39, $305-326$.

Azam, J., Gubert, F., 2005. Those in Kayes: The impact of remittances on their recipients in Africa. Revue Economique 56, 1331-1358.

Batista, C., Lacuesta, A., Vicente, P., 2012. Testing the 'brain gain' hypothesis: Micro evidence from Cape Verde. Journal of Development Economics 97, 32-45.

Becker, G.S., 1993. Nobel lecture: The economic way of looking at behavior. Journal of Political Economy 101, 385-409.

Becker, G.S., 1996. Accounting for Tastes. Harvard University Press, Cambridge.

Beine, M., Docquier, F., Rapoport, H., 2008. Brain drain and human capital formation in developing countries: Winners and losers. The Economic Journal 118, 631-652. 
Bernheim, B.D., Schleifer, A., Summers, L.H., 1985. Strategic bequest motive. Journal of Political Economy 93, 1045-1076.

Bredeloup, S., 1994. L'aventure contemporaine des diamantaires sénégalais. Politique Africaine 56, 77-93.

Cox, D., 1987. Motives for private income transfers. The Journal of Political Economy $95,508-546$.

Cox, D., Stark, O., 1996. Intergenerational transfers and the demonstration effect. Mimeo, Department of Economics, Boston College.

Cox-Edwards, A., Ureta, M., 2003. International migration, remittances, and schooling: Evidence from El Salvador. The Journal of Development Economics 72, 429-461.

Delaunay, D., 1984. De la Captivité à l'Exil : Histoire et Démographie des Migrations Paysannes dans la Moyenne Vallée du Fleuve Sénégal. Paris: ORSTOM.

Demonsant, J.L., 2007. Un système informel de retraite basé sur le prestige des notables au village: Etude de cas à Matam (Sénégal), in: Antoine, P. (Ed.), Les Relations Intergénérationnelles en Afrique : Approche Plurielle.. Paris : CEPED, pp. 121-142.

Demonsant, J.L., 2008. How Family Prestige can Shape Intergenerational Transfers : Migration, Remittances and Schooling in Matam, Senegal. Ph.D. thesis. Université de Toulouse. Toulouse School of Economics ARQADE.

Diop, A.B., 1965. Société Toucouleur et migration. Enquête sur l'immigration Toucouleur à Dakar. Dakar: IFAN.

Docquier, F., Rapoport, H., forthcoming. Globalization, brain drain, and development. Journal of Economic Literature .

Evans, W.N., Schwab, R.M., 1995. Finishing high school and starting college: Do catholic schools make a difference? Quarterly Journal of Economics 110(4).

Gibson, J., McKenzie, D., 2011. Eight questions about brain drain. Journal of Economic Perspectives 5, 107-128. 
Hoddinott, J., 1992. Rotten kids or manipulative parents: Are children old-age security in Western Kenya? Economic Development and Cultural Change 40, 545-565.

Huet-Gueye, M., de Léonardis, M., 2005. Society's representations and educational practices in context of cultural disparity: school attendance's choices for the child among Senegalese parents. Psychologie Française 52, 183-197.

Kandel, W., Kao, G., 2001. The impact of temporary labor migration on Mexican children's educational aspirations and performance. International Migration Review 35, $1205-1231$.

Klein, M., 2005. The concept of honour and the persistence of servility in the Western Soudan. Cahiers d'Etudes Africaines 45, 831-851.

Lucas, R., Stark, O., 1985. Motivation to remit: Evidence from Botswana. The Journal of Political Economy 93, 901-918.

Luke, N., Munshi, K., 2011. Women as agents of change: Female income and mobility in India. Journal of Development Economics 94, 1-17.

McKenzie, D., Rapoport, H., 2011. Can migration reduce educational attainment? evidence from Mexico. Journal of Population Economics 24, 1331-1358.

Minvielle, J.P., 1985. Paysans Migrants du Fouta Toro. La Vallée du Sénégal. ORSTORM.

Montgomery, M., Hewett, P., 2005. Poverty and children's schooling in urban and rural Senegal. Policy Research Division, Population Council. Working Paper No. 196.

Mountford, A., 1997. Can a brain drain be good for growth in the source economy? Journal of Development Economics 53, 287-303.

Munshi, K., Rosenzweig, M., 2006. Traditional institutions meet the modern world: Caste, gender, and schooling choice in a globalizing economy. American Economic Review 96, $1225-1252$.

N'Gaide, A., 2003. Stéréotypes et imaginaires sociaux en milieu Haalpulaar : Classer, stigmatiser et toiser. Cahiers d'Etudes Africaines 172, 707-738. 
Rapoport, H., Docquier, F., 2006. The economics of migrants' remittances, in: Kolm, S.C., Ythier, J.M. (Eds.), Handbook of the Economics of Giving, Altruism and Reciprocity, Volume 2. Elsevier, pp. 1135-1198.

Schmitz, J., 1994. Cités noires : les républiques villageoises du Fuuta Tooro (vallée du fleuve Sénégal). Cahiers d'Etudes Africaines 133-135, 419-460.

Stark, O., Helmenstein, C., Prskawetz, A., 1997. A brain gain with a brain drain. Economics Letters 55, 227-234.

Stark, O., Helmenstein, C., Prskawetz, A., 1998. Human capital depletion, human capital formation, and migration: a blessing or a "curse"? Economics Letters 60, 363-367.

Tamari, T., 1991. The development of caste system in West-Africa. The Journal of African History $32,221-250$.

UNESCO, 2007. Senegal Country Case Study. Technical Report. Country Profile commissioned for the Education For All Global Monitoring Report.

Veblen, T., 1899. The Theory of the Leisure Class: an Economic Study of Institutions. London: Allan and Unwin. Reprinted New-York: Modern Library, 1934.

Wane, Y., 1969. Les Toucouleurs du Fouta Toro: Stratification Sociale et Structure Familiale. Dakar: IFAN.

Weber, M., 1922. Economy and Society. Translated and reprinted. Berkeley: University of California Press, 1978.

Yang, D., 2008. International migration, remittances and household investment: Evidence from Philippine migrants' exchange rate shocks. The Economic Journal 118, 591-630. 